\title{
Does Residence in an Ethnic Community Help Immigrants in a Recession? ${ }^{1}$
}

\author{
Pengyu Zhu \\ Boise State University \\ pengyuzhu@boisestate.edu \\ Cathy Yang Liu \\ Georgia State University \\ cyliu@gsu.edu \\ Gary Painter \\ University of Southern California \\ gpainter@price.usc.edu
}

\begin{abstract}
Research on how the residential segregation of immigrant populations has impacted their labor market outcomes presents many challenges because of the fact that immigrants often choose to locate near co-ethnics to share resources and cultural amenities. Because not all immigrants choose to live in these ethnic communities, identification of a causal effect on living in an ethnic community is difficult. The estimation of an effect of living in these ethnic communities is also difficult because it is ambiguous whether such residence will help or harm the labor market outcomes of immigrants. This study implements a number of approaches to help identify a causal effect, including using sample of adults whose residential location is plausibly exogenous with respect to their labor market outcomes and using the current recession as a source of exogenous variation. Results suggest that residence in an ethnic community after the recession increases the likelihood of working, albeit with longer commutes.
\end{abstract}

\footnotetext{
1 We thank session participants at the Lincoln Institute of Land Policy conference, "Present and Retrospect: The Work of John M. Quigley.” We also thank seminar participants at USC, AREUEA, and APPAM. We also thank Ric Kolenda for his excellent research assistance.
} 


\section{Introduction}

Most literature on the spatial mismatch hypothesis has focused on how the residential segregation of African-Americans has disadvantaged them as jobs have moved to suburban areas. Only a few studies have examined Hispanic or immigrant populations (e.g. Ihlanfeldt 1993, Aponte 1996, Preston et al 1998, Pastor and Marcelli 2000, Parks 2004a and 2004b; Painter, Liu and Zhuang, 2007; Liu, 2009). Some of these studies find that skills' mismatch between immigrants and the needs of their proximate employers are more important than space, while others find residential location is related to the labor market outcomes of immigrants. In addition, most studies have focused on a single large immigrant gateway like New York or Los Angeles, and it may be the case that immigrants have very different experiences in metropolitan areas with fewer immigrants. Hellerstein, Neumark and McInerney (2008) is a recent exception that conducts an analysis with a nationwide metropolitan area sample.

What makes the study of how the labor market outcomes of immigrants are influenced by residential location particularly interesting is the fact that immigrants often choose to locate near co-ethnics to share resources and cultural amenities (Logan, Alba, and Zhang, 2002). Despite the fact that this residential segregation is largely by choice, ${ }^{2}$ it is still possible that choosing to live in an ethnic community can lead to worse labor market outcomes if job market opportunities are moving away from these ethnic neighborhoods (Liu and Painter, 2012a). At the same time, access to ethnic networks may help labor market outcomes, especially in times of economic hardship.

\footnotetext{
${ }^{2}$ This study is not discounting the existence of discrimination against immigrants. See a recent Urban Institute review (http://www.urban.org/UploadedPDF/1001156_Discrimination.pdf) for evidence for its existence.
} 
In order to determine how the residential clustering of Latino immigrants affects their employment outcomes, we use the 2000 Decennial Census 5 percent Integrated Public Use Microdata Series (IPUMS) sample and the 2008-2010 American Community Survey (ACS) microdata. In so doing, we examine three labor market outcomes: employment probability, wages, and commuting time. We define Latino ethnic communities where Latinos immigrants concentrate in the metropolitan areas according to the methodology in Liu (2009). Unlike African American communities that have been traditionally segregated in central cities, immigrant communities are frequently located in suburbs (Li, 1998; Logan, Alba, and Zhang 2002; Liu and Painter 2012b). ${ }^{3}$ The models use data from four metro areas (Atlanta, Washington, D.C., Chicago, and Los Angeles) that differ based on each area’s classification as an immigrant gateway.

Our identification strategy is based on a number of different modeling approaches that will each, in part, address the endogeneity of location choice and car ownership. First, we select a sample of non-householder adults that live with family. The assumption is that these adults are likely to have chosen to live with family for reasons other than access to the labor market. Next, we estimate models both before and after the recession. We argue that the recession introduced an exogenous shock that enable us to compare whether residence in an ethnic community after the recession affects an immigrant's labor market outcomes. Finally, we provide instrumental variables estimates for car ownership (Raphael and Rice 2002) to account for the fact that residential location, car ownership, and labor market outcomes could be simultaneously determined.

\footnotetext{
${ }^{3}$ As discussed below, we test the impact of locating in ethnic communities within central cities, inner ring, and outer ring suburbs. A number of recent studies (Stoll 1999; Pastor 2001; McConville and Ong 2003, Liu, 2009) have acknowledged such differences and shown that it is important to consider the inner ring suburbs separately from the outer ring suburbs.
} 
Our results demonstrate that residence in an ethnic community increased the probability of finding work albeit with longer commutes after the recession. This result contrasts with estimates drawn from 2000 Census data: residents of ethnic communities in central cities, inner ring, or outer ring suburbs fared worse in the labor market than did residents outside those communities. This pattern of results was strongest for new immigrants.

\section{Literature Review}

\section{Ethnic Community Residence and Immigrant Labor Market Outcomes}

The level of residential segregation remains high for immigrants, in general, and Latino immigrants, in particular (Cutler, Glaeser and Vigdor, 2008; Lichter et al, 2009). While their residential location patterns are shaped both by voluntary choice and market conditions, it is important to understand the labor market implications of their ethnic concentration. Theoretically, it is ambiguous whether residence in ethnic communities facilitates or hampers immigrants’ economic achievement. Various theoretical frameworks offer different predictions on the effect of ethnic enclave residence on the employment status, earnings, and commuting behaviors of immigrants. ${ }^{4}$ Comparisons between Latino workers and black workers in segregated neighborhoods have found that immigrant enclaves do not resemble traditional ghettos because of their rich social and ethnic capital and vibrant informal economies (Clark, 2001; Cutler and Glaeser 1997; Borjas 1998; Edin et.al. 2003). Neighborhood-based social networks and contacts connect immigrants to jobs, making them less spatially constrained to the local labor

\footnotetext{
${ }^{4}$ In this research, we use the terms ethnic enclave and ethnic community interchangeably. In the traditional literature, the term ethnic enclave referred to ethnic concentrations in central cities. Since the Alba, Logan, and Zhang (2002) work recognizing the diversity of location and type of ethnic communities, the terms have been used more interchangeably.
} 
market (Portes, 1998; Bertrand et al, 2000; Elliot \& Sims, 2001). By facilitating information flow, social networks ease the job-matching process between workers and employers and increase efficiency on both ends (Rodriguez 2004).

Other research suggests that living in an ethnic enclave lowers the rate of acquisition of host country-specific human capital (Chiswick 1991; Lazear 1999). Living in an ethnic community discourages immigrants from interacting with natives and reduces the incentives for acquiring local skills, such as language, thereby adversely affecting immigrants’ labor market outcomes in the long run. Chiswick and Miller (2005) hypothesize that ethnic minorities may be willing to accept a job at a lower wage rate if the job is located in an ethnic enclave, as they are compensated by other ethnic amenities.

Empirical literature on the direction and magnitude of enclave effect on immigrant's economic outcomes is also mixed. Pastor and Marcelli (2000) found that individual skills matter more than "pure" spatial mismatch in Los Angeles, especially for recent Latino immigrants. Also for Los Angeles, Parks (2004) found that being in enclaves has significantly detrimental effect on the employment status for certain immigrant women groups. Using quasi-experimental design, Damm (2006) and Edin et al (2003) established positive earnings premium for immigrants living in ethnicallyconcentrated areas in Denmark and Sweden, respectively. Others, however, find linguistic concentration leads to lower English language skills and lower earnings in the U.S. (Chiswick and Miller, 2005).

It is important to note that immigrants are increasingly settling away from the central cities within metro areas (Singer et al 2008, Massey 2008). Recent studies have characterized this increasingly decentralized residential pattern as "ethnoburbs" (Li 
1998), “melting pot suburbs” (Frey 2001) and "suburban immigrant nation” (Hardwick 2008). Thus, it is important to make a distinction among ethnic communities located in different parts of the metropolitan area. Liu (2009) documents that Latino immigrants living in job-poor central cities tend to have both lower employment probability and longer commutes than their inner-ring suburban counterparts, though residents in outerring suburban enclaves had longer commutes despite higher employment rates.

\section{Recession and Its Impact on Immigrants}

The current Great Recession, which started in December 2007 and ended in June 2009, started in the housing and financial markets and quickly spread throughout all sectors. National unemployment rate rose from $4.9 \%$ in 2007 to $9.7 \%$ in 2009 - the highest level since 1983 (Sahin, Song and Hobijn 2009). The recession also slowed the inflow of new immigrants (Passel and Cohn, 2010) and further intensified the debate on immigration and how immigrants impact the broader job market (Kochhar, Espinoza, and Hinze-Pifer 2010; Pollin and Wicks-Lim 2011). Research finds immigrants’ employment patterns are more volatile and cyclical over business cycles due to their relative youth, average low skill level, and concentration in cyclically sensitive industries and occupations (Orrenius and Zavodny 2009).

Because the recession has a broad impact on immigrant labor market outcomes, this study uses the recession as a shock that is exogenous to the residential location of immigrants. Therefore, observation of immigrant labor market outcomes within an ethnic community is subject to less endogeneity bias that might exist in a similar study during normal economic times. No study has explicitly examined how the economic downturn 
is experienced by immigrants living in different communities within the metropolitan areas-- central cities versus suburbs, in and out of ethnic enclaves. It is an open question how an immigrant's networks will benefit them in a recession. This study will not be able to test directly the impact of these networks. However, because the overall economy has fallen, it can be argued that what remains for immigrants in these communities is their networks.

\section{Model Specification}

A standard specification of a labor market outcomes model would be the following:

$$
Y_{i}=\beta_{0}+\beta_{1} S_{i}+\beta_{2} X_{i}+\beta_{3} T_{i}+\mu_{i}
$$

$\mathrm{S}_{\mathrm{i}}$ is a set of variables related to the residential location of the immigrant household. We classify location by residence in the central city, inner ring suburbs, or outer ring suburbs. In addition, immigrant households will be classified by residence in ethnic enclaves or not. ${ }^{5} \mathrm{X}_{\mathrm{i}}$ is a set of individual and household socioeconomic characteristics that have been found to be relevant for job prospects based on the labor market literature. These variables include age, gender, marital status, children, experience, educational attainment, household non-labor income ${ }^{6}$, length of time in the United States, and English speaking capability. $\mathrm{T}_{\mathrm{i}}$ is a variable related to transportation characteristics, such as car ownership or commute mode.

$\mathrm{Y}_{\mathrm{i}}$ are a set of labor market outcomes. When estimating the effects of residential segregation on employment propensity, a probit model specification is used. As the

\footnotetext{
${ }^{5}$ Immigrant enclave dummies are constructed on the PUMA level, indicating those PUMAs that have 1.5 times or higher concentration of Latino immigrant population than the metro as a whole based on calculations of residential concentration quotient (RCQ) as defined in Liu (2009).

${ }^{6}$ We use household non-wage income, rather than household total wage, in the model to avoid the simultaneity problems associated with the dependent variables.
} 
literature suggests, low-income minority workers suffers from spatial mismatch partly because they are transit-dependent. Thus the transportation characteristics $T_{i}$ represent the number of vehicles in the household and the same applies to OLS regression on (log) wages.

The problem with estimating a standard model is that the identification of the impact of living in an ethnic community is based on the difference in labor market outcomes for those living inside vs. outside the ethnic community. This strategy would be compromised if there are differences in unobservable characteristics that lead an immigrant to locate inside the ethnic community that are related to their labor market outcomes. One strategy to overcome the endogeneity of location choice is to use a sample of adults who are not householders. A number of studies have used young adults that live with their parents (O’Regan and Quigley, 1991, 1998; Painter et al, 2007; Raphael, 1998). We have extended this logic to include all relatives of the householders (excluding the spouses of the householders), under the assumption that they did not control the location decision. This strategy is especially relevant for immigrants who are more likely to live with shared living arrangements than are native populations.

This strategy leads to the following sample selection. The sample includes Latino immigrants who were in the labor force between ages 16 and 65. Those people who lived in group quarters are excluded from the sample. When studying wage and commute time, the sample is further restricted to those who were employed (including self-employed) in the 2000 Census and 2008-2010 ACS. Observations with zero wages or zero commute time are dropped in corresponding models. The sample is further restricted to include only relatives of household heads. These include children, children-in-law, parents, 
parents-in-law, siblings, siblings-in-law, grandchildren, and other relatives. Note that the spouses of householders are not included in this sample because they are likely to be involved in location decision-making process as much as the householders. Finally, we also estimate models which further restrict the sample to include only the children of householders as a further robustness check because the assumption of exogeneity of location choice is stronger in this sample.

[Table 1 about here]

Summary statistics of these two estimate samples and a full sample that includes all Latino immigrants age 16-65 are presented in Table 1. For both 2000 and 2010, the full sample has the best labor market outcomes, followed by our main and alternative samples. This is not surprising because our main samples are younger and less experienced than the full sample.

A second strategy to achieve identification involves comparing estimates before and after the recession. While it would be ideal to estimate a model where we could difference the data, we cannot do this since the data are a series of cross sections. Instead, we compare the estimates of the impact of living in an ethnic community both before and after the recession. Because of reduced mobility after the recession, it is less likely that householders would be able to move in response to changing economic conditions. Further, because the job market impact was widespread across the metropolitan, we argue that the remaining effect of living in an ethnic community is due to the importance of ethnic networks.

Finally, we are also concerned with endogeneity associated with car ownership (Raphael and Rice 2002). As noted in the literature, car ownership affects possibility of 
getting a job and wage earnings, and finding a job or higher wage also increases the likelihood of car ownership. In addition, when estimating the effects of residential segregation on commute duration, the commute mode choice is not likely to be exogenous. Commute mode will certainly affect commuting time; on the other hand, the length of commuting time will also influence people’s choice of commute mode. To address the endogeneity problem associated car ownership or commute mode, ${ }^{7}$ we use an Instrumental Variable (IV) approach, with three instrumental variables - the number of household members with age above 16, the PUMA level minimum car insurance quote (e.g., Ong 2002; Raphael and Rice 2002; Ong and Miller 2005), ${ }^{8}$ and whether the PUMA has railway stations (Liu and Painter 2012). These instruments influence the number of vehicles in a household, as well as the commute mode choice (i.e., the likelihood of taking public transit), ${ }^{9}$ but none of them directly affects the employment propensity, wage and commute time, except through their impact on the transportation variables.

\section{Data}

The primary datasets for this study are the 2000 Decennial Census 5\% Public Use

$$
\text { Microdata Sample (PUMS) and the 2008-2010 American Community Survey (ACS) }
$$

microdata. These data files feature a very detailed list of demographic, socioeconomic and commuting variables for households and individuals that are appropriate for the

\footnotetext{
${ }^{7}$ The transportation variable used for the employment propensity model and wage model is the number of vehicles in the household. The transportation variable used for the commute time model is the commute mode.

${ }^{8}$ Following previous studies, we use the website www.realquote.com to obtain the PUMA level minimum auto insurance premium. Geographic variation in minimum auto insurance quote is obtained by putting in the characteristics of a same hypothetical applicant across all zip codes, taking the average of quotes from several insurance agencies on the zip-code level, and then aggregating to the PUMA level using GIS techniques. This hypothetical applicant is a twenty-five-year-old employed non-smoking single mother who has a driving record of 7 years with no accidents. Her car is a 1990 Ford Escort LX, two-door hatchback with no antitheft devices, no antilock brakes, no airbags, and is parked on the street. She has only the minimum insurance required $(\$ 15,000 / 30,000$ bodily liability and \$5,000 property liability) with no deductibles.

${ }^{9}$ The number of household adult members affects commute mode choice through its impact on the number of vehicles in household.
} 
research questions in this study. The smallest geographic identifier given in PUMS is Public Use Microdata Area (PUMA): statistical areas with at least 100,000 residents which remain consistent boundaries for 2000 Census and 2008-2010 ACS. ${ }^{10}$

This study focuses on a diversity of metropolitan areas with different size and growth of the immigrant population. These metropolitan areas are Los Angeles, Chicago, Atlanta, and Washington, D.C. ${ }^{11}$ These four metros were chosen because they represent a continuum of types of immigrant gateway metropolitan areas and contain a large number of Latino immigrants: Atlanta and Washington, D.C. are classified as "emerging gateways”, Chicago and Los Angeles are viewed as “continuous gateway” or “postWWII gateway,” respectively, according to Singer (2004).

\subsection{Urban Geography Partitions}

This paper partitions each metropolitan area into three areas: central city, inner ring suburbs and outer ring suburbs (Liu, 2009). This design captures different transit accessibility and job accessibility associated with various locations. In partitioning the urban geography, the designation of central cities follows the "principal cities” definition by the Office of Management and Budget (OMB) in 1999 and includes the City of Atlanta, City of Chicago, City of Los Angeles, and District of Columbia respectively. The determination of inner ring suburban counties draws upon the "first suburbs" methodology developed in Puentes and Warren (2006) which base their identification on age, location and population of counties. Specifically, those counties that were part of the census-identified 1950 Standard Metropolitan Area (SMA) and either contain or are

\footnotetext{
${ }^{10}$ In the text and tables, we will often refer to the $2008-2010$ period as 2010 to economize on the presentation.

${ }^{11}$ In this paper, these four metropolitan areas refer to Los Angeles-Riverside-Orange County, CA CMSA, Chicago-Gary-Kenosha, IL-IN-WI CMSA, Atlanta, GA MSA, and Washington, DC-MD-VA-WV PMSA.
} 
adjacent to one of the primary cities are termed as first suburbs. In this paper, Cook County, IL, Lake County, IN, Los Angeles County, CA, Montgomery County and Prince George County, MD, as well as Arlington County, VA are coded inner ring suburbs. The exceptions is Atlanta: certain PUMAs are selected to comprise the inner ring suburbs based on their proximity to the central city as well as age of housing stock (detailed PUMA partition provided in Appendix A, adapted from Liu 2012). The rest of counties (areas) that make up the metropolitan areas are considered outer ring suburbs. The employment growth patterns for each ring in those four cities between 2000 and 2010 are provided in Table 2 to show the job opportunities associated with these locations.

[Table 2 about here]

Due to the recent recession, employment in three out of the four metropolitan areas declined between 2000 and 2010 (-4.6\% for Los Angeles, -8.3\% for Chicago, and 4.8\% for Atlanta), with the exception of Washington, D.C. (an increase of 8.9\%). The distribution of those changes however was not even across the three rings. The outer ring suburbs in all MSAs enjoyed the fastest growth (for DC and Atlanta) or smallest job loss (for Los Angeles and Chicago) over the time period. In Chicago, its central city suffered

greater job loss than inner ring suburbs, but in all other metros the central city fared better than their inner ring suburbs after the recession. These variations in job growth imply differential job accessibility for their residents.

\subsection{Identifying Ethnic Communities}

Following Liu (2009) and Liu and Painter (2012), we calculate the PUMA level “ethnic community” dummy variable using a residential concentration quotient (RCQ) 
based on Latino concentration in each PUMA. ${ }^{12}$ This paper uses the threshold of RCQ $>1.5$ for Latino ethnic communities in all study areas. ${ }^{13}$ Using this definition, the cut-off level of Latino population share that makes a PUMA qualified as a Latino ethnic enclave in 2000 were 15.7\% in Atlanta, 30.9\% in Chicago, 67.4\% in Los Angeles, and 20.8\% in Washington, D.C. In 2010, the cut-off level of Latino population concentration were $9.8 \%$ in Atlanta, $25.0 \%$ in Chicago, 60.8\% in Los Angeles, and $13.8 \%$ in Washington, D.C. In 2000, 9 out of 33 PUMAs in Atlanta, 10 out of 61 PUMAs in Chicago, 17 out of 110 PUMAs in Los Angeles, and 6 out of 32 PUMAs in Washington, D.C. are considered Latino immigrant enclaves. In 2010, most of the enclaves remained the same. However, there are a total of 8 PUMAs that became enclave communities and a total of 5 PUMAs lost their enclave status from 2000 among all 4 MSAs. This leads to a delineation of six types of communities: ethnic enclaves and non-enclaves in central city, inner ring suburbs and outer ring suburbs respectively (Figure 1). ${ }^{14}$

[Figure 1 about here]

[Table 3 about here]

Mean employment rates for Latino immigrants living in and out of ethnic communities located in three rings in all four metropolitan areas are presented in Table 3. There are important changes in the employment patterns across residential locations between 2000 and 2010. In 2000, most enclave residents had lower employment rates than non-enclave residents, with employment probabilities lowest in central cities and

\footnotetext{
${ }^{12}$ See Liu (2009) and Liu and Painter (2012) for details about the methodology.

${ }^{13}$ For robustness check, we also tested using RCQ $>2$ as enclave cutoff level. The results of our empirical models are similar to those using RCQ $>1.5$ cutoff level.

${ }^{14}$ Our analyses for 2000 and 2010 are based on the enclave status of PUMAs in each corresponding year. Since there are several PUMAs that changed their enclave status from 2000 to 2010, we tested 2010 analyses using the 2000 PUMA enclave status. The results are similar to what we present in this paper.
} 
highest in outer ring suburbs. The year 2010 saw an overall decline in employment rate, but enclave residents' employment probability surpassed their non-enclave counterparts in several metro rings, especially in Los Angeles and Atlanta. The central city in Los Angeles and Atlanta also had higher employment after the recession.

\section{RESULTS}

5.1 Estimates with sample of relatives of householders

Our main results use a sample of relatives of householders for three labor market outcomes: employment probability, annual wages, and one-way commute times. The full set of results are present in Table 4. Subsequent tables presenting models that use alternative samples and specifications highlight our main variable of interest - the impact of living in an ethnic community across different rings of the metropolitan area.

$<$ Table 4 about here $>$

\section{1) Labor Force Participation}

Model (1) demonstrates that Latino immigrants living in ethnic enclaves are less likely to be employed in 2000. In both the central city and inner ring suburbs, those living in enclaves are about 1 percent less likely to find a job than those not living in enclaves. In outer ring suburbs, that difference is statistically insignificant. However, in 2010, residence in an ethnic community has a very different impact on Latino immigrants' labor force participation (Model 4). In the central city, those living in enclaves are as likely to find a job as those living outside of enclaves; and in both inner ring suburbs and outer ring suburbs, those living in enclaves are about 1 percent more likely to be employed than their non-enclave counterparts. The implication of these 
results is that living in an ethnic community has benefited Latino immigrants during the recent economic recession.

The pattern of results across rings also highlights the big change in employment after the recession. In 2000, residing in the central city or inner ring suburbs predicts lower employment probability among Latino immigrants in comparison to those residing in the outer ring suburbs, consistent with what the spatial mismatch literature has shown. In contrast to results from 2000, those living in central cities are the most likely to be employed after the recession, and those living in outer ring suburbs are the least likely to be employed with significant differences across the three spatial categories. The finding for 2010 is contrary to much of the spatial mismatch literature would suggest, and may be unique to this recessionary period.

Demographic and household socioeconomic factors have a consistent impact on labor force participation in both 2000 and 2010. The number of vehicles in household increases Latino immigrants’ likelihood of employment . Latino immigrants from households with higher non-wage income are less likely to be employed in 2010. Education, age and experience also have the expected effects in both years, with higher levels of education and experience predicting higher likelihood of employment. Marital status does not make a difference in finding a job, but Latino immigrants who are female or have children under age five are less likely to work.

\section{2) Wage}

Models (2) and (5) in Table 4 displays results on the impact of residential location and socioeconomic factors on the annual wage of Latino immigrants in 2000 and 2010. The annual wage of Latino immigrants living in enclaves is likely to be 7 percent lower 
in 2000 in the central city. No statistically significant difference on earnings is found for immigrants located in inner ring and outer ring suburbs. This finding suggests that the impact of ethnic enclaves on earnings varies across urban space, with central city residents experiencing a negative impact from ethnic enclaves while residents in inner ring or outer ring suburbs experiencing no significant impact. Once again, estimates from the 2008-2010 data present a different outcome. After the recession, enclave residence in the inner ring suburbs has a positive impact on earnings, and there is no difference for those enclaves located in central cities and outer ring suburbs.

As expected, the number of vehicles is associated with higher wages in both years. Education, age, and experience increase earnings. Female workers receive lower earnings than male workers in both years net of other factors. Latino immigrants with children under age five have higher earnings, conditional on being employed. The amount of time that an immigrant has been in the United States increases earnings in both 2000 and 2010. Latino immigrants who have better English language skills also earn higher wages. Industry is another important factor in determining earnings; those working in Finance, Insurance, and Real Estate have the highest wage.

\section{3) One-way Commute Duration}

Models (3) and (6) in Table 4 displays results on the one-way commute duration of Latino immigrants in 2000 and 2010, conditional on being employed. OLS results suggest that ethnic enclave residents have longer commutes in both 2000 and 2010. In both years, the effect of living in an ethnic community on commute length is much larger in inner ring and outer ring suburbs than in central cities, suggesting the mismatch effect of ethnic enclaves on commute duration is more dominant in suburbs than in central 
cities. Comparing three urban spatial rings, individuals residing in the central city experienced the longest commute duration in both years, followed by inner ring suburbs and outer ring suburbs.

This model also tests for the impact of taking public transit. As expected, commute by public transit substantially increases the commute time in both 2000 and 2010 (see also Ong and Miller 2005). Among other factors that are both statistically and economically significant, female Latino immigrants’ commute duration tends to be 9 percent less than males in both years, newer immigrants tend to commute 4 percent less time than those who arrived earlier, Latino immigrants working in the Agriculture Mining and Construction industry have consistently longer commute time than those working in other industries.

\subsection{Estimates with sample of children of householders}

Table 5 presents estimates from a sample of the children of householders. The results are not as consistent as in the sample of relatives. First, we note (Model 1) that space played no role in labor force participation in 2000. Higher wages were earned in central city non-enclaves and outer-ring enclaves (Model 2). The only consistent result was that immigrants commuted longer in central city and inner ring enclaves (Model 3).

After the recession, the immigrants that were the most likely to work live in inner ring enclaves and central city non-enclaves (Model 4). Wage differences between enclaves and non-enclave residents had largely disappeared after the recession (Model 5). After the recession, residents in ethnic communities had the longest commutes in the central city and inner ring suburbs, but the differences between residents in the two 
partitions of the central city were not large (Model 6). Overall, we conclude that while the pattern of results is similar with respect to commute times, there are only minor differences between living in ethnic communities and living outside of these communities in this restricted sample.

\subsection{Addressing Endogeneity Associated with Car Ownership}

As discussed earlier, car ownership is likely to be another endogenous variable when studying the labor market outcomes. Table 6 presents the results using an instrumental variables approach to address the endogeneity problem of car ownership (i.e. the number of vehicles in household) or commute mode (i.e. commute by transit) with the same sample from Table 4. A Wald test of exogeneity suggests that these variables in our three models should all be treated as endogenous. Models (1) and (4) in Table 6 uses an IV probit model, while Models (2), (3), (5) and (6) use 2-Stage Least Squares model in the estimation. In all models, the instrumental variables used are number of persons over 16 years old in the household, PUMA level weighted minimum auto insurance, and the availability of rail station in the PUMA.

$<$ Table 6 about here $>$

The results on ethnic enclaves are comparable to those of probit models and OLS models in Table 4. In central city, Latino enclaves unfavorably affect both the likelihood of being employed and the annual wage in 2000, but there are no significant differences in the employment propensities in 2010. In the inner ring suburbs, Latino enclaves significantly reduce the likelihood of being employed in 2000, but increase both the employment propensity and annual wage in 2010. In both years, Latino enclaves increase the commute duration by about $8 \%$ if these enclaves are located in inner ring 
suburbs. In outer ring suburbs, Latino immigrants living in enclaves commute longer than non-enclave immigrants in 2000, and they are more likely to be employed and on average commute longer in 2010.

The IV estimates also provide important findings about the impact of automobile on employment outcomes. Our models suggest that if the number of household vehicles increases by one, the likelihood of finding a job for Latino immigrants increases by 2 percent in 2000 and less than $1 \%$ in 2010. However, wage is not significantly affected by the number of vehicles in both 2000 and 2010. This result is subject to similar interpretation as proposed in Raphael and Rice (2002). PUMAs with higher auto insurance and better public transit accessibility require their residents to receive a wage premium to be able to compensate for the contribution of these factors to the cost of living in these places.

\subsection{Variation by MSA}

It has noted that "continuous gateway” metropolitan areas such as Chicago and Los Angeles have more bounded ethnic communities (Alba, Logan, and Zhang, 2002). Ethnic enclaves in these MSAs are likely to maintain different networks from those in new immigrant destinations. Table 7 presents the results for four MSAs separately. For Los Angeles, Latino immigrants living in ethnic communities are less likely to be employed than those in non-enclaves in 2000, but more likely to be employed in 2010 . The wages are lower for those living in central city ethnic communities in 2000, but are higher for those living in inner ring and outer ring suburb ethnic communities in 2010. For Chicago, Latino immigrants living in non-enclaves are better off in both 2000 and 
2010, in terms of employment propensity. For Atlanta, there are no ethnic communities in central city. In 2000, those living in ethnic communities located in outer ring suburbs had higher earnings. For Washington, Latino immigrants living in central city enclaves fare worse in terms of earnings in both 2000 and 2010. The most consistent results across place are that immigrants are more likely to commute further when living in an ethnic community. Thus, the results are dependent on the type of metropolitan area and the kinds of economic shocks they were subject to. In the two metropolitan areas where construction was such an important industry (Los Angeles and Atlanta), Latino immigrants living inside ethnic communities are doing better than those living outside of ethnic communities over the economic recession. We do not find this result after the recession in Chicago and Washington.

[Table 7 about here]

\subsection{Other Results}

We next stratified the sample based on the newness of immigrants in the United States to examine the effect of residing in an ethnic community. One concern in using the before and after comparison for this sample is that the Latino immigrant sample has changed after recession. The economic downturn slowed down the immigration inflow from Latin America and some Latino immigrants, especially those who have lost jobs or had difficulty finding one, might have already returned to their home country. These changes might result in a more prepared labor pool in 2010 as compared to 2000, potentially biasing our results. Though we included migration duration as an independent variable in our model, we further stratify the sample into new arrivals (those who arrived 
in less than 10 years) and established immigrants (arrived more than 10 years) to gauge the enclave effect on these two groups. There is also reason to believe that new immigrants are more likely to choose to reside in ethnic communities for reasons other than the job market so this sample may be less contaminated by endogeneity bias. Results from these model stratifications are reported in Appendix 3.

The results from the new immigrant sample closely mirror the results from Table 4. In particular, new immigrants that live in ethnic communities after the recession are more likely to have longer commutes across all regions of the metropolitan area. The differences in employment propensities between enclave and non-enclave residents are only significant in the outer ring suburbs. There is also a positive wage premium in the inner ring suburbs that did not exist in 2000. Results on the role of living in an ethnic community for the immigrant sample that had been in the country for more than 10 years are mostly insignificant after the recession. The results prior to the recession were consistent with the results for the new immigrant sample. This suggests that benefits of living in the network are largely confined to new immigrants.

Finally, we compare results from the Latino immigrant sample to an African American sample because African Americans may be equally disadvantaged in their residential location and job accessibility but presumably do not benefit from Latino ethnic networks. Such a comparison further help to separate the network effect from location effect for Latino immigrants. The results are reported in Appendix 4. While African American workers living in central cities also suffer from lower employment outcomes in 2000, the positive enclave effect we observe for Latino immigrants in 2010 is not present for the African Americans in the same locations. Further, commutes are not 
longer for African Americans that live in areas designated as Latino enclaves. This provides important evidence that the positive ethnic networks that exist in these communities benefit only Latino immigrant workers.

\section{Conclusion}

This study uses a variety of samples and comparisons across time to provide identification of the role of ethnic networks for Latino immigrants in 4 metropolitan areas. The results demonstrate Latino immigrants had a higher probability of finding a job during and after the recession although they tended to commute further to those jobs if they lived in an ethnic community. In the inner ring suburbs, immigrants in ethnic communities also were more likely to have higher wages. We find that car ownership and transit mode choice are endogenous variables, and that results on the importance of those variables change after using instrumental variable models. However, the results on the role of space on the labor market outcomes of immigrants after the recession are unchanged.

The results of this study suggest strongly that ethnic networks do help immigrants find jobs during time of economic hardship. Under the assumption that the economic shock affected the formal labor market uniformly across the metropolitan area, immigrants that lived outside of these networks had lower wages and fewer jobs because they did not have the same links to network connections as did residents of ethnic communities. Importantly, results from the African American sample suggest that there was nothing related to job accessibility in these areas that could explain these results. 
Further, evidence from the new immigrant sample highlights the fact that new immigrants are most likely to receive these benefits.

Despite the strong evidence that networks are likely helping immigrants in the recessions, this research does not provide us with any mechanism by which these networks operate. Further research is needed to learn how immigrants find jobs within ethnic communities and whether the benefits of networks are extant in normal economic times. In addition, research is needed to discover how immigrants have been impacted by economic shocks throughout the country. Evidence suggests that millions of immigrants have moved to large numbers of metropolitan areas (Painter and Yu, 2010), and we do not know how the recession has impacted immigrants in areas without long standing ethnic communities. 


\section{References}

Aponte, R. (1996) Urban employment and the mismatch dilemma: accounting for the immigration exception, Social Problems, 43(3): 268-283.

Bertrand, M., Luttmer, E., Mullainathan, S. (2000) "Network Effects and Welfare Cultures," Quarterly Journal of Economics, 115 (1): 1019-1055.

Borjas, G. (1998). To Ghetto or Not to Ghetto: Ethnicity and Residential Segregation. Journal of Urban Economics, 10504 (1): 228-253.

Chiswick, B. R. (1991). Speaking, Reading, and Earnings among Low-Skilled Immigrants. Journal of Labor Economics, 9(2): 149-170.

Chiswick, B. R. \& P. W. Miller. (2005). The Endogeneity between Language and Earnings: International Analyses. Journal of Labor Economics 13(2): 246-288.

Clark, W. A. V. (2001). The geography of immigrant poverty: Selective evidence of an immigrant underclass. In R. Waldinger (Ed.), Strangers at the gates: New immigrants in Urban America (159-187). Berkeley and Los Angeles: University of California Press.

Cutler, D.M. \& Glaeser E.L. (1997). Are ghettos good or bad? Quarterly Journal of Economics, 112(3): 827-872.

Cutler, D. M., Glaeser, E. L. and Vigdor, J. L. (2008). Is the melting pot still hot? Explaining the resurgence of immigrant segregation. The Review of Economics and Statistics, 90(3): 478-497.

Damm, A.P. (2006). Ethnic enclaves and immigrant labour market outcomes: Quasiexperimental evidence. Discussion Paper. Center for Research and Analysis of Migration: London, UK.

Elliott, J. R. \& Sims, M. (2001). Ghettos and barrios: the impact of neighborhood poverty and race on job matching among blacks and Latinos. Social Problems, 48(3): 341-361.

Edin, P., Fredriksson, P., Aslund, O. (2003). Ethnic enclaves and the economic success of immigrants-evidence from a natural experience. The Quarterly Journal of Economics, 118(1): 329-357.

Frey, W. H. (2001). Melting pot suburbs: a census 2000 study of suburban diversity. Center on Urban and Metropolitan Policy, The Brookings Institution, Washington, DC.

Hardwick, S. W. (2008). Toward a suburban immigrant nation, in: A. Singer, S. W. Hardwick and C. B. Brettell (Eds) Twenty-first Century Gateways: Immigrant Incorporation in Suburban America, 31-50. Washington, DC: Brookings Institution Press 
Hellerstein, J. K., Neumark, D. \& McInerney, M. (2008). Spatial mismatch or racial mismatch? Journal of Urban Economics, 64(2): 464-479.

Ihlanfeldt, K. R. (1993). Intra-urban job accessibility and Hispanic youth employment rates. Journal of Urban Economics, 33(1): 254-271.

Kochhar, R., Espinoza, C. S., and Hinze-Pifer, R. (2010) After the great recession: Foreign born gain jobs; Native born lose jobs. Pew Hispanic Center Report, October 2010.

Lazear, E. P. (1999). Culture and Language. Journal of Political Economy, 107(6): S95S126.

Li, W. (1998). Anatomy of a new ethnic settlement: The Chinese ethnoburb in Los Angeles. Urban Studies, 35 (3): 479-501.

Lichter, D. T., Parisi, D., Taquino, M. C., Grice, S. M. (2010). Residential segregation in new Hispanic destinations: cities, suburbs, and rural communities compared. Social Science Research, 39(1): 215-230.

Liu, C. Y. (2009). Ethnic Enclave Residence, employment, and commuting of Latino workers. Journal of Policy Analysis and Management, 28(4): 600-625.

Liu, C. Y. (2012) Intrametropolitan Opportunity Structure and the Self-employment of Asian and Latino Immigrants. Economic Development Quarterly, 26 (2):178-192.

Liu, C. Y. \& Painter, G. (2012a). Immigrant settlement and employment suburbanization in the US: Is there a spatial mismatch? Urban Studies, 50(4): 1-24.

Liu, C. Y. \& Painter, G. (2012b). Travel behavior among Latino immigrants: The role of ethnic concentration and ethnic employment. Journal of Planning Education and Research, 32(1):1-19.

Logan, J. R., Alba R. D., Zhang W. Q. (2002). Immigrant enclaves and ethnic communities in New York and Los Angeles. American Sociological Review, 67 (2): 299322

Massey, D. S. (2008). New Faces in New Places: The Changing Geography of American Immigration. New York: Russell Sage Foundation

McConville, S. \& Ong, P. (2003). The trajectory of poor neighborhoods in Southern California, 1970-2000. Washington, DC: Center on Urban and Metropolitan Policy, The Brookings Institution.

Ong, P. M. (2002). Car ownership and welfare-to-work. Journal of Policy Analysis and Management, 21(2): 255-68. 
Ong, P. M. \& Miller, D. (2005). Spatial and transportation mismatch in Los Angeles. Journal of Planning Education and Research, 25 (1): 43-56.

O’Regan, K. M. and Quigley, J. M. (1991). Labor-market access and labor-market outcomes for urban youth. Regional Science and Urban Economics, 21(2): 277-293.

O'Regan, K. M. and Quigley, J. M. (1998). Where youth live: economic effects of urban space on employment prospects. Urban Studies, 35(7): 1187-1205.

Orrenius, P.M., and Zavodny, M. (2009) Tied to the business cycle: How immigrants fare in good and bad economic times? Migration Policy Institute, Washington, D.C. (November 2009).

Painter, G. and Z. Yu (2010), "Immigrants and Housing Markets in Mid-size Metropolitan Areas," International Migration Review, 44(2) 442-476.

Painter, G., Liu, C. Y., Zhuang, D. (2007). Immigrants and spatial mismatch hypothesis: Employment outcomes among immigrant youth in Los Angeles. Urban Studies, 44(13): 2627-2649.

Parks, V. (2004a). Access to work: the effects of spatial and social accessibility on unemployment for native-born Black and immigrant women in Los Angeles, Economic Geography, 80(2):141-172.

Parks, V. (2004b). The gendered connection between ethnic residential and labor-market segregation in Los Angeles, Urban Geography, 25(7): 589-630.

Passel, J. S., and Cohn, D. (2010). U.S. unauthorized immigration flows are down sharply since mid-decade. Pew Hispanic Center report, October 2010.

Pastor, M. \& Marcelli, E. (2000). Social, spatial and skill mismatch among immigrants and native-born workers in Los Angeles. Working Paper No. 1, Center for Comparative Immigration Studies, University of California, San Diego.

Pollin, R., and Wicks-Lim, J. (2011) Did immigrants in the U.S. labor market make conditions worse for native workers during the Great Recession? PERI Working Paper Series, Number 246.

Portes, A. (1998). Social capital: Its origins and application in modern sociology. Annual Review of Sociology, 24 (1):1-24.

Preston, V., McLafferty, S. and Liu, X. F. (1998) Geographical barriers to employment for American-born and immigrant workers. Urban Studies, 35(3): 529-545. 
Puentes, R., \& D. Warren. (2006). One-fifth of America: A comprehensive guide to America's first suburbs. Washington, DC: Center on Urban and Metropolitan Policy, The Brookings Institution

Raphael, S. (1998). The spatial mismatch hypothesis and black youth joblessness: evidence from the San Francisco Bay area. Journal of Urban Economics, 43(1): 79-111.

Raphael, S. \& Rice, L. (2002). Car ownership, employment, and earnings. Journal of Urban Economics, 52(1): 109-130.

Sahin, A., Song, J., and Hobijn, B. (2010) The unemployment gender gap during the current recession. Current Issues in Economics and Finance, 16(2), 1-7.

Singer, A. (2004). The rise of new immigrant gateways. Center on Urban and Metropolitan Policy, The Brookings Institution, Washington, DC.

Stoll, M.A. (1999). Spatial mismatch, discrimination, and male youth employment in the Washington, DC area: Implications for residential mobility policies. Journal of Policy Analysis and Management, 18(1): 77-98. 


\section{Figure 1 Location of Ethnic Communities 2000 and 2010}

\section{Los Angeles CMSA by PUMA 2000 and 2010}

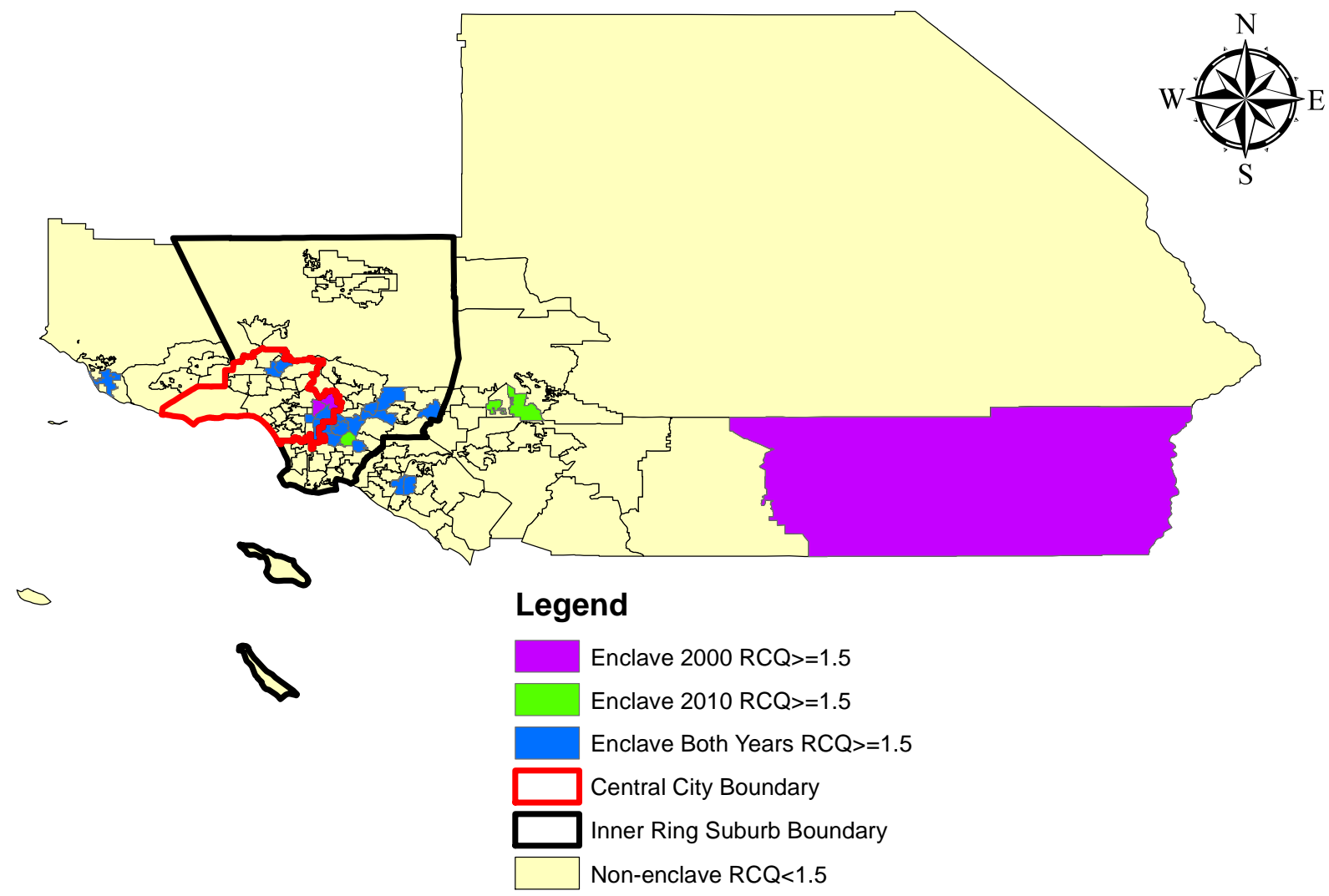




\section{Chicago CMSA by PUMA 2000 and 2010}

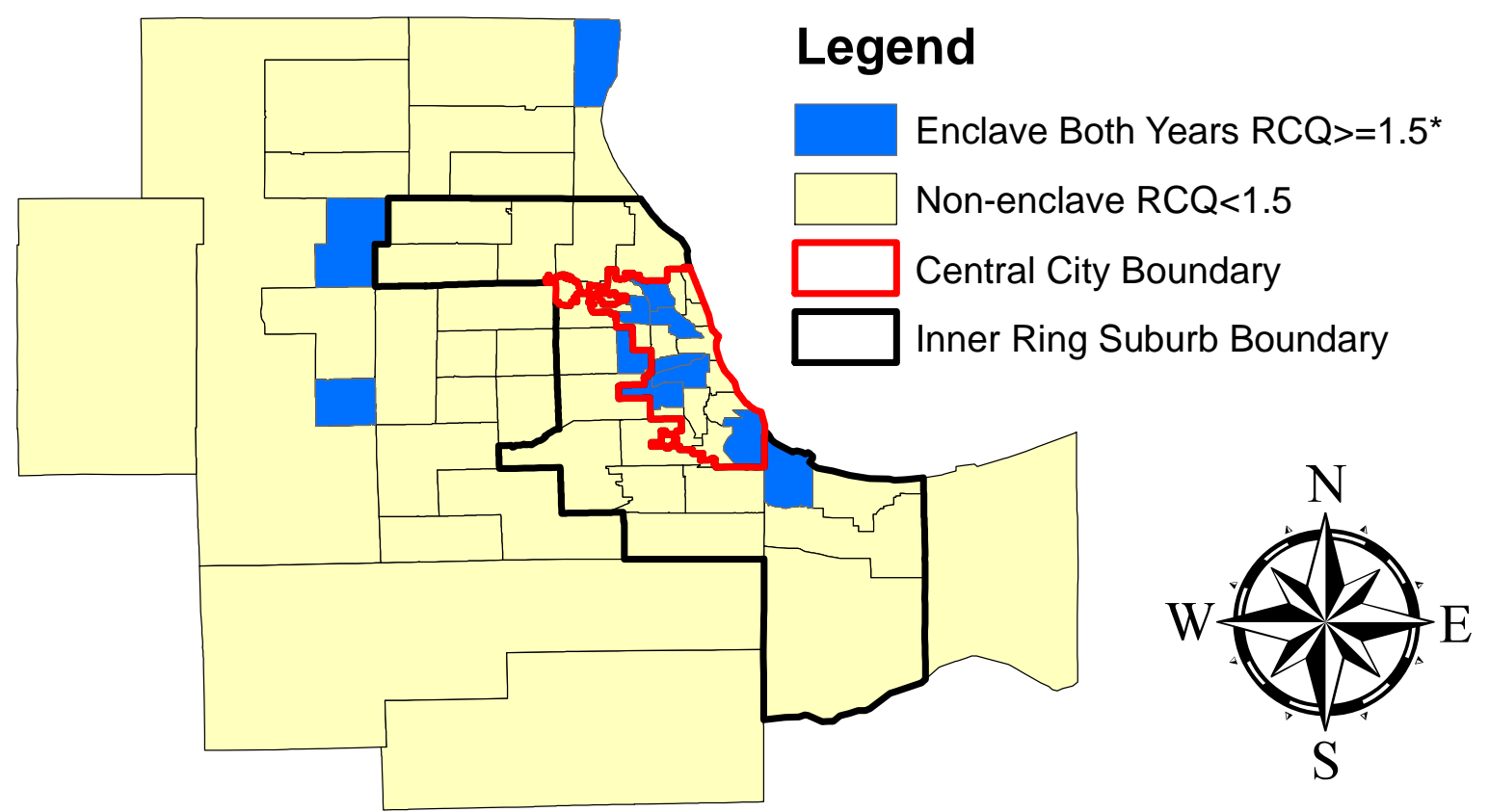

*PUMA enclaves in 2000 were identical to those in 2010 


\section{Washington DC CMSA by PUMA 2000 and 2010}
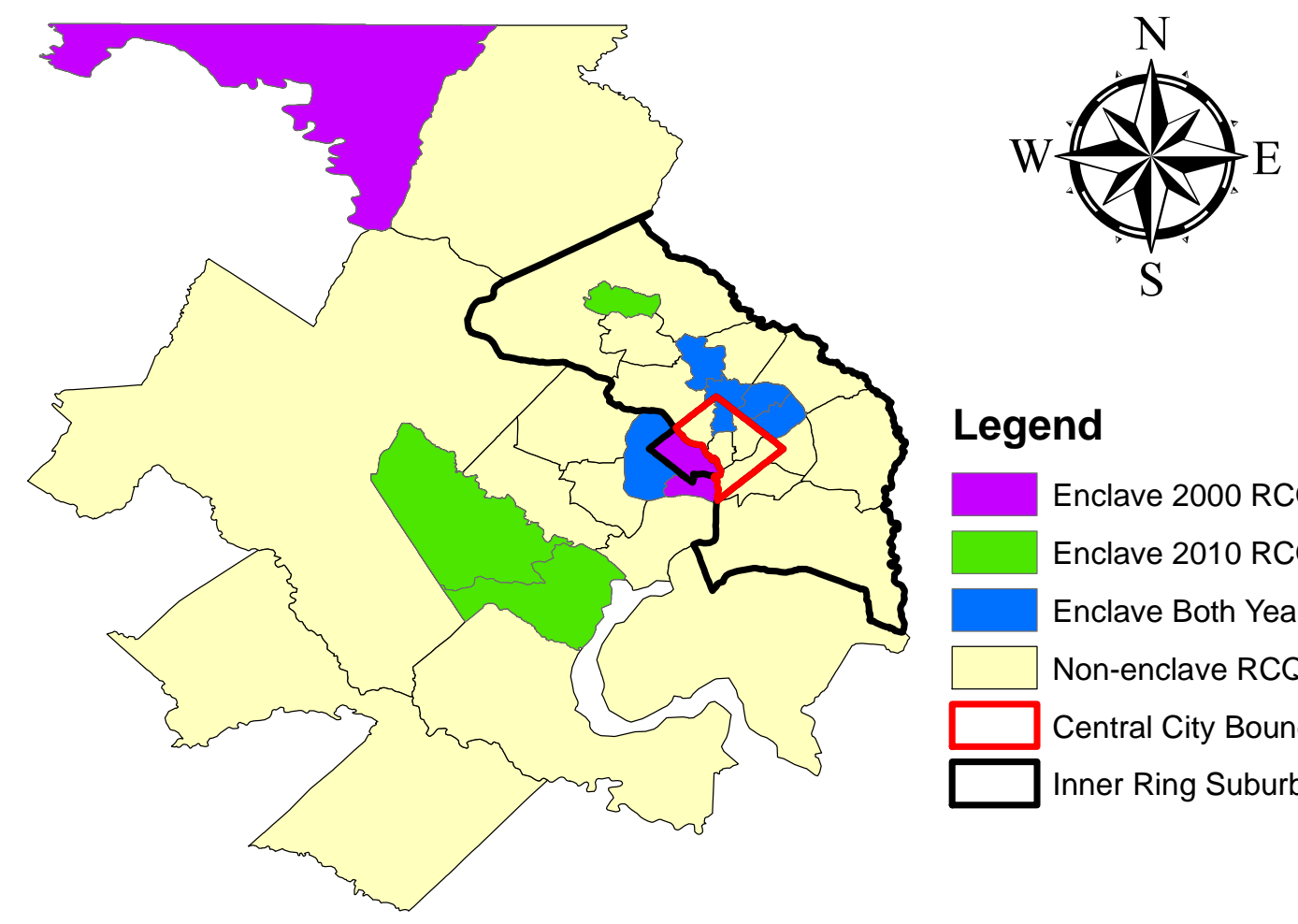

Legend

Enclave $2000 \mathrm{RCQ}>=1.5$

Enclave $2010 \mathrm{RCQ}>=1.5$

Enclave Both Years RCQ $>=1.5$

$\square$
Non-enclave $R C Q<1.5$

$\square$ Central City Boundary

$\square$ Inner Ring Suburb Boundary 


\section{Atlanta MSA by PUMA 2000 and 2010}
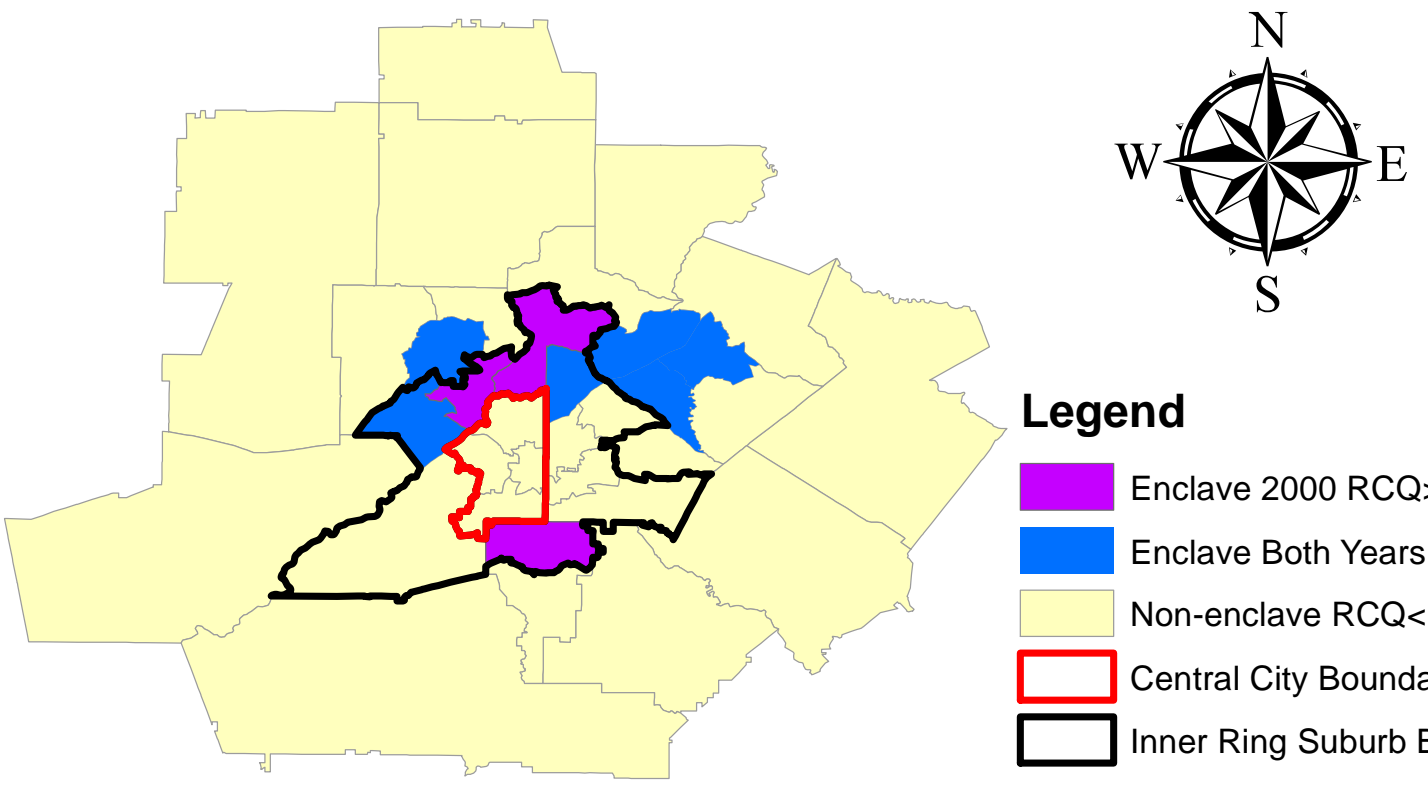

\section{Legend}

Enclave $2000 \mathrm{RCQ}>=1.5^{\star}$
Enclave Both Years $\mathrm{RCQ}>=1.5^{\star}$
Non-enclave $\mathrm{RCQ}<1.5$
$\square$ Central City Boundary
$\square$ Inner Ring Suburb Boundary

*No unique PUMA enclaves in 2010 
Table 1 Summary of variables in different samples, 2000 and 2010

\begin{tabular}{|c|c|c|c|c|c|c|}
\hline \multirow{2}{*}{ Variable } & \multicolumn{3}{|c|}{2000 Mean } & \multicolumn{3}{|c|}{2010 Mean } \\
\hline & $\begin{array}{c}\text { Full } \\
\text { Sample }\end{array}$ & $\begin{array}{c}\text { Relatives } \\
\text { Sample }\end{array}$ & $\begin{array}{l}\text { Children } \\
\text { Sample }\end{array}$ & $\begin{array}{c}\text { Full } \\
\text { Sample }\end{array}$ & $\begin{array}{c}\text { Relatives } \\
\text { Sample }\end{array}$ & $\begin{array}{l}\text { Children } \\
\text { Sample }\end{array}$ \\
\hline \multicolumn{7}{|l|}{ Dependent Variables } \\
\hline Employment rate & 0.91 & 0.89 & 0.87 & 0.90 & 0.88 & 0.80 \\
\hline Wage & 19264 & 14079 & 13962 & 26897 & 20120 & 16970 \\
\hline One-way commute duration & 30.42 & 30.78 & 28.52 & 28.51 & 28.92 & 25.58 \\
\hline \multicolumn{7}{|l|}{ Independent Variables } \\
\hline Household non-wage income & 6044 & 6250 & 8095 & 8226 & 9052 & 10525 \\
\hline Number of vehicles & 1.85 & 1.96 & 2.30 & 2.22 & 2.40 & 2.61 \\
\hline Number of adults (over age 16) & 3.71 & 4.68 & 4.79 & 3.37 & 4.15 & 4.40 \\
\hline Less than highschool & 0.61 & 0.62 & 0.54 & 0.49 & 0.49 & 0.37 \\
\hline Highschool diploma, some college & 0.30 & 0.32 & 0.38 & 0.38 & 0.41 & 0.55 \\
\hline College degree or above & 0.09 & 0.06 & 0.07 & 0.13 & 0.09 & 0.08 \\
\hline Age & 35.29 & 29.84 & 24.59 & 39.86 & 33.59 & 23.53 \\
\hline Experience & 17.93 & 12.59 & 7.11 & 22.19 & 16.03 & 5.68 \\
\hline Female & 0.38 & 0.35 & 0.41 & 0.40 & 0.37 & 0.40 \\
\hline Presence of child & 0.22 & 0.06 & 0.11 & 0.17 & 0.07 & 0.09 \\
\hline Married & 0.59 & 0.26 & 0.28 & 0.60 & 0.24 & 0.20 \\
\hline Arrived in the US in last 10 years & 0.35 & 0.53 & 0.46 & 0.50 & 0.68 & 0.76 \\
\hline Arrived in the US $10-20$ years ago & 0.36 & 0.31 & 0.35 & 0.30 & 0.22 & 0.19 \\
\hline Arrived in the US $20-30$ years ago & 0.22 & 0.13 & 0.17 & 0.16 & 0.08 & 0.05 \\
\hline Arrived in the US over 30 years & 0.08 & 0.03 & 0.02 & 0.05 & 0.02 & 0.01 \\
\hline Agriculture, mining, construction & 0.16 & 0.18 & 0.13 & 0.18 & 0.19 & 0.13 \\
\hline Manufacturing & 0.24 & 0.22 & 0.20 & 0.17 & 0.16 & 0.11 \\
\hline Trade & 0.23 & 0.27 & 0.31 & 0.23 & 0.28 & 0.38 \\
\hline FIRE & 0.03 & 0.02 & 0.04 & 0.03 & 0.03 & 0.04 \\
\hline Personal and business services & 0.27 & 0.25 & 0.27 & 0.31 & 0.28 & 0.27 \\
\hline Public Administration & 0.06 & 0.05 & 0.06 & 0.08 & 0.06 & 0.06 \\
\hline Speak English only & 0.05 & 0.04 & 0.04 & 0.04 & 0.03 & 0.03 \\
\hline Speak English well & 0.51 & 0.46 & 0.65 & 0.53 & 0.51 & 0.73 \\
\hline Speak English poor & 0.44 & 0.49 & 0.31 & 0.43 & 0.46 & 0.24 \\
\hline Central city enclave & 0.17 & 0.17 & 0.18 & 0.11 & 0.13 & 0.13 \\
\hline Central city nonenclave & 0.15 & 0.14 & 0.13 & 0.16 & 0.17 & 0.16 \\
\hline Inner ring suburb enclave & 0.18 & 0.19 & 0.20 & 0.16 & 0.17 & 0.17 \\
\hline Inner ring suburb nonenclave & 0.18 & 0.16 & 0.18 & 0.19 & 0.17 & 0.19 \\
\hline Outer ring suburb enclave & 0.10 & 0.11 & 0.11 & 0.10 & 0.11 & 0.11 \\
\hline Outer ring suburb nonenclave & 0.23 & 0.23 & 0.20 & 0.28 & 0.25 & 0.24 \\
\hline Atlanta & 0.04 & 0.05 & 0.02 & 0.05 & 0.05 & 0.03 \\
\hline Chicago & 0.15 & 0.14 & 0.15 & 0.14 & 0.13 & 0.15 \\
\hline Washington D.C. & 0.07 & 0.08 & 0.06 & 0.09 & 0.10 & 0.08 \\
\hline Los Angeles & 0.74 & 0.73 & 0.76 & 0.72 & 0.72 & 0.74 \\
\hline Number of Observations & 106898 & 34781 & 6913 & 74046 & 20325 & 2582 \\
\hline
\end{tabular}

Notes:

1. Variables "wage", "commute time", "AMC", "Manufacturing", "Trade", "FIRE", "Services", "Public" are calculated based on a subsample of Latino immigrants who are employed. 
Table 2 Number and Growth of Jobs by Ring (2000-2010)

\begin{tabular}{ccrrrrr}
\hline & MSA & Los Angeles & \multicolumn{1}{c}{ Chicago } & Washington, DC & \multicolumn{1}{c}{ Atlanta } & \multicolumn{1}{c}{ Total } \\
\cline { 2 - 7 } 2000 & Central City & $1,426,628$ & $1,249,249$ & 414,983 & 559,773 & $3,235,650$ \\
& Inner Ring Suburbs & $2,437,243$ & $1,203,401$ & 851,097 & 792,793 & $4,433,437$ \\
& Outer Ring Suburbs & $2,475,152$ & $1,446,535$ & 916,355 & 849,860 & $4,771,547$ \\
& Total & $6,339,023$ & $3,899,185$ & $2,182,435$ & $2,202,426$ & $12,440,634$ \\
\cline { 2 - 7 } 2010 & Central City & $1,358,423$ & $1,078,322$ & 463,076 & 491,116 & $3,390,937$ \\
& Inner Ring Suburbs & $2,221,644$ & $1,091,265$ & 843,150 & 652,263 & $4,808,322$ \\
& Outer Ring Suburbs & $2,465,139$ & $1,406,437$ & $1,070,961$ & 953,031 & $5,895,568$ \\
& Total & $6,045,206$ & $3,576,024$ & $2,377,187$ & $2,096,411$ & $14,094,828$ \\
\cline { 2 - 7 } $2000-10$ & Central City & $-68,205$ & $-170,927$ & 48,093 & $-68,657$ & $-259,696$ \\
Change & Inner Ring Suburbs & $-215,599$ & $-112,136$ & $-7,947$ & $-140,530$ & $-476,212$ \\
& Outer Ring Suburbs & $-10,013$ & $-40,098$ & 154,606 & 103,171 & 207,666 \\
& Total & $-293,817$ & $-323,161$ & 194,752 & $-106,015$ & $-528,241$ \\
\cline { 2 - 7 } $2000-2010$ & Central City & $-4.8 \%$ & $-13.7 \%$ & $11.6 \%$ & $-12.3 \%$ & $-8.0 \%$ \\
Percent Change & $-8.8 \%$ & $-9.3 \%$ & $-0.9 \%$ & $-17.7 \%$ & $-10.7 \%$ \\
& Inner Ring Suburbs & $-0.4 \%$ & $-2.8 \%$ & $16.9 \%$ & $12.1 \%$ & $4.4 \%$ \\
& Outer Ring Suburbs & $-4.6 \%$ & $-8.3 \%$ & $8.9 \%$ & $-4.8 \%$ & $-4.2 \%$ \\
\hline
\end{tabular}

Source: County Business Patterns and Zip-code Business Pattern for Los Angeles, Chicago and Washington,D.C.

* Data for Atlanta are based on calculations from 2010 census tracts data provided by Atlanta Regional

Commission. 
Table 3 Employment Rate by Ring and Enclave Status in 4 MSAs, 2000-2010

\begin{tabular}{lcccccccccc}
\hline \multicolumn{1}{c}{ MSA } & \multicolumn{1}{c}{ Los Angeles } & \multicolumn{2}{c}{ Chicago } & \multicolumn{2}{c}{ Washington } & \multicolumn{2}{c}{ Atlanta } & \multicolumn{2}{c}{ Total } \\
& 2000 & 2010 & 2000 & 2010 & 2000 & 2010 & 2000 & 2010 & 2000 & 2010 \\
& & & & & & & & & & \\
central city enclave & $89.5 \%$ & $90.7 \%$ & $91.1 \%$ & $87.9 \%$ & $92.8 \%$ & $87.9 \%$ & - & - & $90.1 \%$ & $89.6 \%$ \\
central city non-enclave & $90.1 \%$ & $90.5 \%$ & $92.8 \%$ & $93.3 \%$ & $95.0 \%$ & $93.8 \%$ & $91.8 \%$ & $93.7 \%$ & $90.5 \%$ & $90.8 \%$ \\
inner ring suburb enclave & $90.3 \%$ & $91.0 \%$ & $91.8 \%$ & $90.6 \%$ & $93.2 \%$ & $90.7 \%$ & $94.0 \%$ & $92.1 \%$ & $91.2 \%$ & $91.0 \%$ \\
inner ring suburb non-enclave & $91.6 \%$ & $90.3 \%$ & $93.3 \%$ & $92.1 \%$ & $94.7 \%$ & $92.6 \%$ & $92.9 \%$ & $91.9 \%$ & $92.1 \%$ & $90.9 \%$ \\
outer ring suburb enclave & $91.5 \%$ & $89.1 \%$ & $93.1 \%$ & $90.7 \%$ & $95.9 \%$ & $92.6 \%$ & $93.9 \%$ & $89.2 \%$ & $92.3 \%$ & $89.9 \%$ \\
outer ring suburb non-enclave & $92.0 \%$ & $88.1 \%$ & $94.0 \%$ & $89.5 \%$ & $95.5 \%$ & $93.7 \%$ & $93.9 \%$ & $89.8 \%$ & $92.6 \%$ & $88.9 \%$ \\
\hline
\end{tabular}

Source: author's calculation of Decennial Census 2000 and ACS 2008-10 PUMS data 
Table 4 Results for employment outcomes of latino immigrants who are relatives of householders

\begin{tabular}{|c|c|c|c|c|c|c|}
\hline & \multicolumn{3}{|c|}{2000} & \multicolumn{3}{|c|}{2010} \\
\hline $\begin{array}{l}\text { Dep. Var.: Employed } \\
\text { Independent Variables }\end{array}$ & $\begin{array}{c}1) \\
\text { Emp } \\
\text { Propensity } \\
\text { (Probit) } \\
\end{array}$ & $\begin{array}{c}(2) \\
\text { Wage } \\
(\text { log) } \\
\text { (OLS) } \\
\end{array}$ & $\begin{array}{c}(3) \\
\text { Commute } \\
\text { Time (log) } \\
\text { (OLS) } \\
\end{array}$ & $\begin{array}{c}(4) \\
\text { Emp } \\
\text { Propensity } \\
\text { (Probit) } \\
\end{array}$ & $\begin{array}{c}(5) \\
\text { Wage } \\
(\text { log) } \\
(\mathrm{OLS}) \\
\end{array}$ & $\begin{array}{c}(6) \\
\text { Commute } \\
\text { Time (log) } \\
\text { (OLS) } \\
\end{array}$ \\
\hline Central city enclave & $\begin{array}{l}-0.017^{* * *} \\
(-3.17)\end{array}$ & $\begin{array}{c}-0.069^{* * *} \\
(-4.34)\end{array}$ & $\begin{array}{l}0.130^{* * *} \\
(9.71)\end{array}$ & $\begin{array}{l}0.030^{* * *} \\
(3.60)\end{array}$ & $\begin{array}{l}-0.004 \\
(-0.20)\end{array}$ & $\begin{array}{l}0.134^{* * *} \\
(7.15)\end{array}$ \\
\hline Central city non-enclave & $\begin{array}{l}-0.007 \\
(-1.27)\end{array}$ & $\begin{array}{l}-0.014 \\
(-0.85)\end{array}$ & $\begin{array}{l}0.120^{* * *} \\
(8.61)\end{array}$ & $\begin{array}{c}0.034^{* * *} \\
(4.60)\end{array}$ & $\begin{array}{l}0.016 \\
(0.85)\end{array}$ & $\begin{array}{l}0.116^{* * *} \\
(6.81)\end{array}$ \\
\hline Inner ring suburb enclave & $\begin{array}{c}-0.014^{* * *} \\
(-2.66)\end{array}$ & $\begin{array}{l}0.013 \\
(0.84)\end{array}$ & $\begin{array}{l}0.114^{* * *} \\
(8.89)\end{array}$ & $\begin{array}{l}0.023^{* * *} \\
(3.19)\end{array}$ & $\begin{array}{c}0.052^{* * *} \\
(2.76)\end{array}$ & $\begin{array}{l}0.095^{* * *} \\
(5.73)\end{array}$ \\
\hline Inner ring suburb non-enclave & $\begin{array}{l}-0.008 \\
(-1.51)\end{array}$ & $\begin{array}{l}0.006 \\
(0.41)\end{array}$ & $\begin{array}{l}0.034^{* *} \\
(2.57)\end{array}$ & $\begin{array}{l}0.016^{\star *} \\
(2.28)\end{array}$ & $\begin{array}{l}0.036^{*} \\
(1.95)\end{array}$ & $\begin{array}{l}0.014 \\
(0.86)\end{array}$ \\
\hline Outer ring suburb enclave & $\begin{array}{l}0.003 \\
(0.52)\end{array}$ & $\begin{array}{l}0.022 \\
(1.29)\end{array}$ & $\begin{array}{l}0.040^{* * *} \\
(2.76)\end{array}$ & $\begin{array}{l}0.016^{*} \\
(1.89)\end{array}$ & $\begin{array}{l}0.023 \\
(1.06)\end{array}$ & $\begin{array}{l}0.065^{\star * *} \\
(3.40)\end{array}$ \\
\hline $\begin{array}{l}\text { Household nonwage income } \\
\text { (normalized) }\end{array}$ & $\begin{array}{l}-0.005 \\
(-1.31)\end{array}$ & $\begin{array}{l}0.005 \\
(0.48)\end{array}$ & $\begin{array}{c}0.018^{* *} \\
(2.15)\end{array}$ & $\begin{array}{c}-0.008^{* * *} \\
(-2.67)\end{array}$ & $\begin{array}{l}0.014 \\
(1.51)\end{array}$ & $\begin{array}{l}0.009 \\
(1.12)\end{array}$ \\
\hline Household num of vehicles & $\begin{array}{l}0.012^{* * *} \\
(9.29)\end{array}$ & $\begin{array}{l}0.044^{* * *} \\
(12.40)\end{array}$ & - & $\begin{array}{l}0.014^{* * *} \\
(7.71)\end{array}$ & $\begin{array}{l}0.043^{* * *} \\
(9.59)\end{array}$ & - \\
\hline Commute by public transit & $\begin{array}{l}- \\
-\end{array}$ & $\begin{array}{l}- \\
-\end{array}$ & $\begin{array}{l}0.566^{* * *} \\
(49.74)\end{array}$ & - & - & $\begin{array}{c}0.599 * * * \\
(38.97)\end{array}$ \\
\hline Edu. less than highschool & $\begin{array}{c}-0.016^{* * *} \\
(-2.84)\end{array}$ & $\begin{array}{c}-0.117^{* * *} \\
(-6.92)\end{array}$ & $\begin{array}{l}-0.007 \\
(-0.47)\end{array}$ & $\begin{array}{c}-0.028^{* * *} \\
(-3.19)\end{array}$ & $\begin{array}{c}-0.061^{* * *} \\
(-2.61)\end{array}$ & $\begin{array}{l}-0.003 \\
(-0.13)\end{array}$ \\
\hline Edu. college degree or above & $\begin{array}{l}0.017 \\
(1.54)\end{array}$ & $\begin{array}{c}0.128^{* * *} \\
(4.30)\end{array}$ & $\begin{array}{l}-0.032 \\
(-1.28)\end{array}$ & $\begin{array}{l}0.017 \\
(1.13)\end{array}$ & $\begin{array}{l}0.025 \\
(0.67)\end{array}$ & $\begin{array}{l}0.062^{*} \\
(1.85)\end{array}$ \\
\hline Age & $\begin{array}{c}0.020^{* * *} \\
(4.60)\end{array}$ & $\begin{array}{c}0.057^{* * *} \\
(4.40)\end{array}$ & $\begin{array}{c}0.025^{\star *} \\
(2.32)\end{array}$ & $\begin{array}{c}0.023^{* * *} \\
(3.88)\end{array}$ & $\begin{array}{c}0.123^{* * *} \\
(7.70)\end{array}$ & $\begin{array}{l}0.012 \\
(0.88)\end{array}$ \\
\hline Age squared & $\begin{array}{c}0.000^{* * *} \\
(-3.98)\end{array}$ & $\begin{array}{l}-0.000 \\
(-0.97)\end{array}$ & $\begin{array}{l}-0.000 \\
(-1.40)\end{array}$ & $\begin{array}{c}-0.000^{* * *} \\
(-5.08)\end{array}$ & $\begin{array}{c}-0.001^{* * *} \\
(-4.04)\end{array}$ & $\begin{array}{l}-0.000 \\
(-0.41)\end{array}$ \\
\hline Experience & $\begin{array}{c}-0.006^{* *} \\
(-2.01)\end{array}$ & $\begin{array}{l}0.007 \\
(0.81)\end{array}$ & $\begin{array}{l}-0.010 \\
(-1.37)\end{array}$ & $\begin{array}{l}-0.003 \\
(-0.75)\end{array}$ & $\begin{array}{c}-0.034^{* * *} \\
(-2.89)\end{array}$ & $\begin{array}{l}-0.002 \\
(-0.23)\end{array}$ \\
\hline Experience squared & $\begin{array}{c}0.000^{* *} \\
(2.01)\end{array}$ & $\begin{array}{c}-0.001^{* * *} \\
(-6.39)\end{array}$ & $\begin{array}{l}0.000 \\
(0.36)\end{array}$ & $\begin{array}{c}0.000^{* *} \\
(2.39)\end{array}$ & $\begin{array}{c}-0.001^{* * *} \\
(-3.05)\end{array}$ & $\begin{array}{l}-0.000 \\
(-0.44)\end{array}$ \\
\hline Female & $\begin{array}{c}-0.046^{\star * *} \\
(-13.42)\end{array}$ & $\begin{array}{c}-0.256^{\star * *} \\
(-23.38)\end{array}$ & $\begin{array}{c}-0.087^{* * *} \\
(-9.43)\end{array}$ & $\begin{array}{c}-0.028^{* * *} \\
(-5.79)\end{array}$ & $\begin{array}{c}-0.272^{\star * \star} \\
(-20.39)\end{array}$ & $\begin{array}{c}-0.092^{* * *} \\
(-7.74)\end{array}$ \\
\hline Children & $\begin{array}{c}-0.019^{* * *} \\
(-2.62)\end{array}$ & $\begin{array}{c}0.058^{* * *} \\
(2.65)\end{array}$ & $\begin{array}{l}0.035^{*} \\
(1.94)\end{array}$ & $\begin{array}{c}-0.027^{* * *} \\
(-2.78)\end{array}$ & $\begin{array}{c}0.055^{\star *} \\
(2.15)\end{array}$ & $\begin{array}{l}-0.010 \\
(-0.45)\end{array}$ \\
\hline Married & $\begin{array}{l}0.003 \\
(0.69)\end{array}$ & $\begin{array}{c}-0.026^{\star *} \\
(-2.23)\end{array}$ & $\begin{array}{l}-0.010 \\
(-1.00)\end{array}$ & $\begin{array}{l}0.006 \\
(0.92)\end{array}$ & $\begin{array}{l}0.002 \\
(0.13)\end{array}$ & $\begin{array}{l}0.007 \\
(0.49)\end{array}$ \\
\hline $\begin{array}{l}\text { Immigration in last } 10 \text { years } \\
(1990-2000)\end{array}$ & $\begin{array}{l}0.006 \\
(1.45)\end{array}$ & $\begin{array}{c}-0.063^{* * *} \\
(-5.27)\end{array}$ & $\begin{array}{l}-0.028^{* * *} \\
(-2.76)\end{array}$ & $\begin{array}{l}0.008 \\
(1.30)\end{array}$ & $\begin{array}{c}-0.098^{* * *} \\
(-6.16)\end{array}$ & $\begin{array}{c}-0.037^{* * *} \\
(-2.63)\end{array}$ \\
\hline $\begin{array}{l}\text { Immigration in } 20-30 \text { years } \\
(1970-79)\end{array}$ & $\begin{array}{l}-0.002 \\
(-0.38)\end{array}$ & $\begin{array}{l}0.132^{* * *} \\
(8.18)\end{array}$ & $\begin{array}{l}-0.009 \\
(-0.66)\end{array}$ & $\begin{array}{l}-0.012 \\
(-1.27)\end{array}$ & $\begin{array}{c}0.093^{* * *} \\
(3.61)\end{array}$ & $\begin{array}{l}0.033 \\
(1.46)\end{array}$ \\
\hline $\begin{array}{l}\text { Immigration over } 30 \text { years } \\
\quad \text { (before 1970) }\end{array}$ & $\begin{array}{l}-0.01 \\
(-0.97)\end{array}$ & $\begin{array}{c}0.230^{* * *} \\
(7.63)\end{array}$ & $\begin{array}{l}-0.023 \\
(-0.90)\end{array}$ & $\begin{array}{l}0.027 \\
(1.51)\end{array}$ & $\begin{array}{c}0.137^{* * *} \\
(3.01)\end{array}$ & $\begin{array}{l}-0.027 \\
(-0.66)\end{array}$ \\
\hline Speak English only & $\begin{array}{l}-0.038^{* * *} \\
(-5.06)\end{array}$ & $\begin{array}{l}0.037 \\
(1.49)\end{array}$ & $\begin{array}{l}0.030 \\
(1.45)\end{array}$ & $\begin{array}{l}-0.006 \\
(-0.40)\end{array}$ & $\begin{array}{c}0.114^{* * *} \\
(3.19)\end{array}$ & $\begin{array}{l}0.011 \\
(0.33)\end{array}$ \\
\hline Speak English well & $\begin{array}{l}-0.002 \\
(-0.50)\end{array}$ & $\begin{array}{l}0.095^{* * *} \\
(8.16)\end{array}$ & $\begin{array}{l}0.003 \\
(0.29)\end{array}$ & $\begin{array}{c}-0.016^{* * *} \\
(-2.94)\end{array}$ & $\begin{array}{l}0.077^{* * *} \\
(5.45)\end{array}$ & $\begin{array}{l}0.033^{* * *} \\
(2.71)\end{array}$ \\
\hline Manufacturing & - & $\begin{array}{l}0.049^{* * *} \\
(3.08)\end{array}$ & $\begin{array}{l}-0.209^{* * *} \\
(-15.62)\end{array}$ & - & $\begin{array}{l}0.032 \\
(1.50)\end{array}$ & $\begin{array}{l}-0.194^{* * *} \\
(-10.55)\end{array}$ \\
\hline Trade & - & $-0.095^{* * *}$ & $-0.326^{* * *}$ & - & $-0.103^{* * *}$ & $-0.301^{* * *}$ \\
\hline
\end{tabular}


Table 5 Results for employment outcomes of latino immigrants who are children of householders

\begin{tabular}{|c|c|c|c|c|c|c|}
\hline & \multicolumn{3}{|c|}{2000} & \multicolumn{3}{|c|}{2010} \\
\hline Dep. Var.: Employed & $\begin{array}{c}(1) \\
\text { Emp } \\
\text { Propensity } \\
\text { (Probit) } \\
\end{array}$ & $\begin{array}{c}(2) \\
\text { Wage } \\
(\text { log) } \\
\text { (OLS) } \\
\end{array}$ & $\begin{array}{c}(3) \\
\text { Commute } \\
\text { Time (log) } \\
\text { (OLS) }\end{array}$ & $\begin{array}{c}(4) \\
\text { Emp } \\
\text { Propensity } \\
\text { (Probit) }\end{array}$ & $\begin{array}{c}(5) \\
\text { Wage } \\
\text { (log) } \\
\text { (OLS) } \\
\end{array}$ & $\begin{array}{c}(6) \\
\text { Commute } \\
\text { Time (log) } \\
\text { (OLS) }\end{array}$ \\
\hline Central city enclave & $\begin{array}{l}-0.025^{*} \\
(-1.95)\end{array}$ & $\begin{array}{l}-0.025 \\
(-0.66)\end{array}$ & $\begin{array}{l}0.146^{\star * *} \\
-4.78\end{array}$ & $\begin{array}{l}0.019 \\
(0.69)\end{array}$ & $\begin{array}{l}0.138^{*} \\
(1.79)\end{array}$ & $\begin{array}{l}0.187^{* * *} \\
(3.37)\end{array}$ \\
\hline Central city non-enclave & $\begin{array}{l}-0.015 \\
(-1.07)\end{array}$ & $\begin{array}{c}0.115^{* * *} \\
(2.75)\end{array}$ & $\begin{array}{l}0.083^{* *} \\
-2.5\end{array}$ & $\begin{array}{c}0.059^{* *} \\
(2.32)\end{array}$ & $\begin{array}{c}0.174^{* *} \\
(2.43)\end{array}$ & $\begin{array}{c}0.167^{* * *} \\
(3.24)\end{array}$ \\
\hline Inner ring suburb enclave & $\begin{array}{l}-0.003 \\
(-0.22)\end{array}$ & $\begin{array}{l}0.038 \\
(1.06)\end{array}$ & $\begin{array}{l}0.090^{* * *} \\
-3.1\end{array}$ & $\begin{array}{c}0.055^{\star *} \\
(2.23)\end{array}$ & $\begin{array}{c}0.169^{* *} \\
(2.49)\end{array}$ & $\begin{array}{c}0.139^{* * *} \\
(2.88)\end{array}$ \\
\hline Inner ring suburb non-enclave & $\begin{array}{c}0.01 \\
(0.74)\end{array}$ & $\begin{array}{l}0.056 \\
(1.52)\end{array}$ & $\begin{array}{l}-0.023 \\
(-0.79)\end{array}$ & $\begin{array}{l}0.027 \\
(1.16)\end{array}$ & $\begin{array}{c}0.147^{* *} \\
(2.20)\end{array}$ & $\begin{array}{l}0.078 \\
(1.64)\end{array}$ \\
\hline Outer ring suburb enclave & $\begin{array}{l}0.025 \\
(1.64)\end{array}$ & $\begin{array}{c}0.094^{* *} \\
(2.22)\end{array}$ & $\begin{array}{l}0.026 \\
-0.78\end{array}$ & $\begin{array}{c}0.02 \\
(0.70)\end{array}$ & $\begin{array}{l}0.048 \\
(0.61)\end{array}$ & $\begin{array}{l}0.024 \\
(0.42)\end{array}$ \\
\hline $\begin{array}{c}\text { Observations } \\
\text { R2 or Pseudo R2 }\end{array}$ & $\begin{array}{l}6913 \\
0.053\end{array}$ & $\begin{array}{l}5,144 \\
0.247\end{array}$ & $\begin{array}{l}5,785 \\
0.121\end{array}$ & $\begin{array}{l}2582 \\
0.068\end{array}$ & $\begin{array}{l}1,977 \\
0.268\end{array}$ & $\begin{array}{l}1,979 \\
0.154\end{array}$ \\
\hline
\end{tabular}

z-statistics in parentheses

${ }^{* * *} p<0.01,{ }^{* *} p<0.05,{ }^{*} p<0.1$

Notes:

1. For enclave dummy variables, the reference is outer ring suburb non-enclave.

2. The Probit models for Employment Propensity report the marginal effects.

3. All control variables are same as in Table 3. For brevity, they are not listed. 
Table 6 Employment outcomes of latino immigrants who are relatives of householders (IV Methods)

\begin{tabular}{|c|c|c|c|c|c|c|}
\hline & \multicolumn{3}{|c|}{2000} & \multicolumn{3}{|c|}{2010} \\
\hline Dep. Var.: Employed & $\begin{array}{c}\text { (1) } \\
\text { Emp } \\
\text { Propensity } \\
\text { (Ivprobit) }\end{array}$ & $\begin{array}{c}(2) \\
\text { Wage } \\
(\text { log) } \\
(2 S L S) \\
\end{array}$ & $\begin{array}{c}(3) \\
\text { Commute } \\
\text { Time (log) } \\
\text { (2SLS) }\end{array}$ & $\begin{array}{c}(4) \\
\text { Emp } \\
\text { Propensity } \\
\text { (Ivprobit) } \\
\end{array}$ & $\begin{array}{c}(5) \\
\text { Wage } \\
(\text { log) } \\
(2 S L S) \\
\end{array}$ & $\begin{array}{c}(6) \\
\text { Commute } \\
\text { Time (log) } \\
\text { (2SLS) }\end{array}$ \\
\hline Central city enclave & $\begin{array}{l}-0.013^{* *} \\
(-2.10)\end{array}$ & $\begin{array}{c}-0.099^{* * *} \\
(-5.61)\end{array}$ & $\begin{array}{l}0.037 \\
(0.59)\end{array}$ & $\begin{array}{l}0.025^{* * *} \\
(2.95)\end{array}$ & $\begin{array}{l}-0.038^{*} \\
(-1.71)\end{array}$ & $\begin{array}{l}0.095^{*} \\
(1.76)\end{array}$ \\
\hline Central city non-enclave & $\begin{array}{l}-0.002 \\
(-0.39)\end{array}$ & $\begin{array}{l}-0.044^{* *} \\
(-2.44)\end{array}$ & $\begin{array}{l}0.038 \\
(0.68)\end{array}$ & $\begin{array}{l}0.029^{* * *} \\
(3.61)\end{array}$ & $\begin{array}{l}-0.027 \\
(-1.29)\end{array}$ & $\begin{array}{l}0.066 \\
(0.99)\end{array}$ \\
\hline Inner ring suburb enclave & $\begin{array}{l}-0.013^{* *} \\
(-2.42)\end{array}$ & $\begin{array}{l}0.005 \\
(0.34)\end{array}$ & $\begin{array}{l}0.088^{* * *} \\
(4.11)\end{array}$ & $\begin{array}{c}0.022^{* \star *} \\
(2.96)\end{array}$ & $\begin{array}{c}0.041^{* *} \\
(2.17)\end{array}$ & $\begin{array}{l}0.080^{* * *} \\
(3.09)\end{array}$ \\
\hline Inner ring suburb non-enclave & $\begin{array}{l}-0.007 \\
(-1.28)\end{array}$ & $\begin{array}{l}-0.001 \\
(-0.09)\end{array}$ & $\begin{array}{l}0.013 \\
(0.68)\end{array}$ & $\begin{array}{c}0.015^{\star *} \\
(2.12)\end{array}$ & $\begin{array}{l}0.028 \\
(1.50)\end{array}$ & $\begin{array}{l}0.003 \\
(0.13)\end{array}$ \\
\hline Outer ring suburb enclave & $\begin{array}{l}0.003 \\
(0.40)\end{array}$ & $\begin{array}{l}0.026 \\
(1.47)\end{array}$ & $\begin{array}{l}0.030^{*} \\
(1.82)\end{array}$ & $\begin{array}{l}0.016^{*} \\
(1.93)\end{array}$ & $\begin{array}{l}0.026 \\
(1.18)\end{array}$ & $\begin{array}{c}0.063^{* * *} \\
(3.23)\end{array}$ \\
\hline $\begin{array}{l}\text { Household num of vehicles } \\
\text { (endogeneous variable) }\end{array}$ & $\begin{array}{l}0.02^{* * *} \\
(4.59)\end{array}$ & $\begin{array}{l}-0.004 \\
(-0.31)\end{array}$ & - & $\begin{array}{l}0.007^{*} \\
(1.89)\end{array}$ & $\begin{array}{l}-0.007 \\
(-0.73)\end{array}$ & - \\
\hline $\begin{array}{l}\text { Commute by Transit } \\
\text { (endogeneous variable) }\end{array}$ & $\begin{array}{l}- \\
-\end{array}$ & - & $\begin{array}{c}0.977^{* * *} \\
(3.56)\end{array}$ & $\begin{array}{l}- \\
-\end{array}$ & $\begin{array}{l}- \\
-\end{array}$ & $\begin{array}{c}0.806^{* * *} \\
(3.03)\end{array}$ \\
\hline $\begin{array}{c}\text { Observations } \\
\mathrm{R} 2 \text { or Pseudo R2 }\end{array}$ & $\begin{array}{c}34781 \\
- \\
\end{array}$ & $\begin{array}{c}26,660 \\
0.148 \\
\end{array}$ & $\begin{array}{c}28,994 \\
0.078 \\
\end{array}$ & $\begin{array}{c}20325 \\
- \\
\end{array}$ & $\begin{array}{c}16,593 \\
0.164 \\
\end{array}$ & $\begin{array}{c}17,123 \\
0.117 \\
\end{array}$ \\
\hline
\end{tabular}

z-statistics in parentheses

${ }^{* * *} p<0.01,{ }^{* *} p<0.05,{ }^{*} p<0.1$

Notes:

1. For enclave dummy variables, the reference is outer ring suburb non-enclave.

2. Three variables are used to instrument for the endogeneous varialbe "vehicles". They are number of persons over 16 years old in the household, PUMA level weighted minimum auto insurance, and the availabitily of rail station in the PUMA.

3. The standard error of coefficient estimates in the second-stage probit model has been adjusted.

4. The IVprobit models for Employment Propensity report the marginal effects.

5. All control variables are same as in Table 3. For brevity, they are not listed. 
Table 7 Results for employment outcomes of latino immigrants who are relatives of householders by MSA

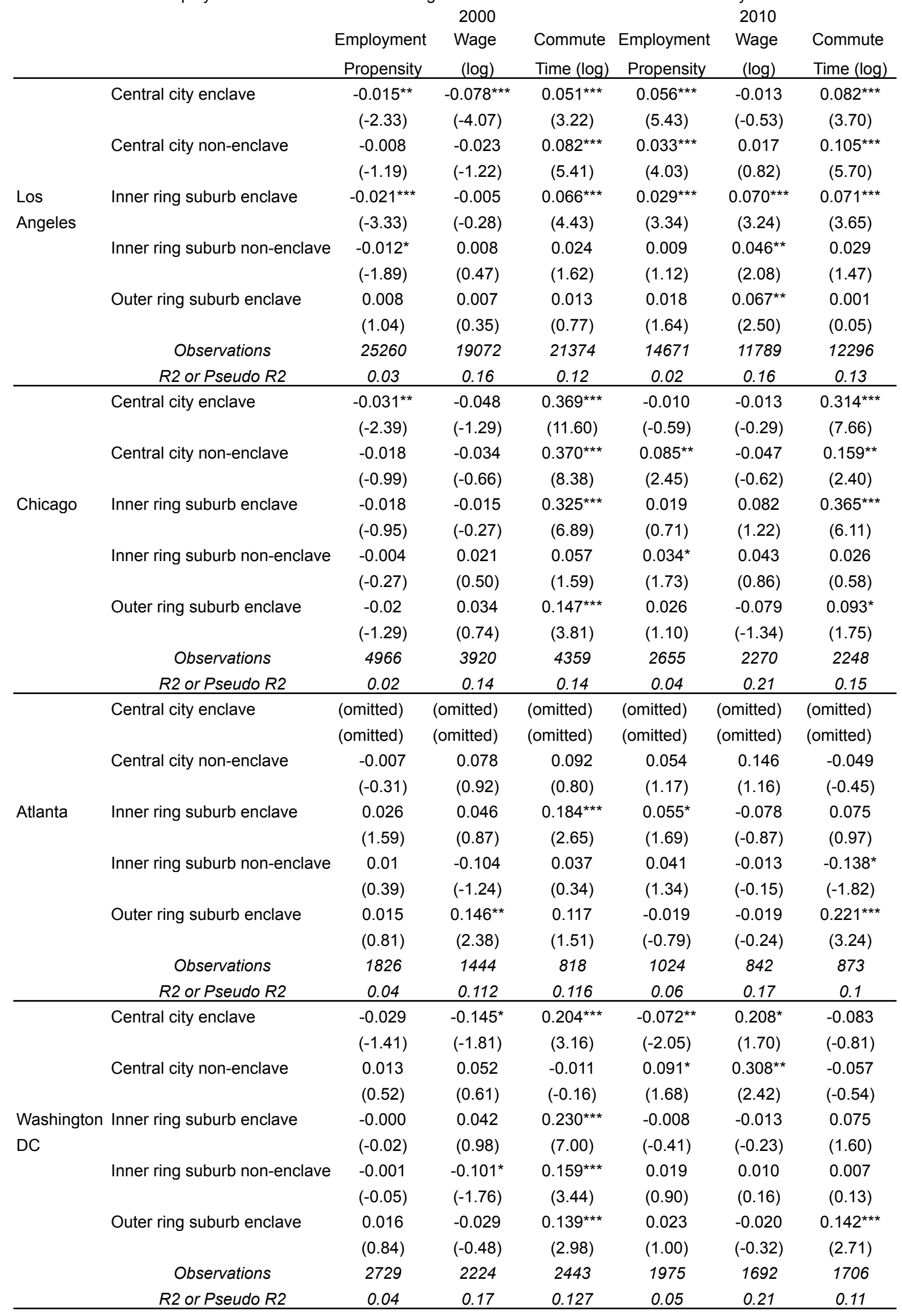


Appendix 1. Age of Housing Stock and Ring Designation by PUMA for Atlanta MSA

\begin{tabular}{|c|c|c|c|}
\hline PUMA & County & $\begin{array}{c}\text { City }^{\mathrm{a}} \\
\text { Central City }\end{array}$ & Median Housing Age \\
\hline 1103 & $\overline{\text { Fulton }}$ & Atlanta & $1960-1969$ \\
\hline 1104 & Fulton & Atlanta & 1940-1949 \\
\hline 1105 & Fulton & Atlanta & $1960-1969$ \\
\hline 1106 & Fulton & Atlanta, College Park \& East Point & 1960-1969 \\
\hline 1201 & DeKalb & Atlanta, Decatur \& Druid Hills & 1950-1959 \\
\hline 1204 & DeKalb & $\begin{array}{l}\text { Belvedere Park \& Candler-McAfee } \\
\text { Inner Ring Suburbs }\end{array}$ & 1960-1969 \\
\hline 1102 & Fulton & Sandy Springs \& Roswell & $1980-1989$ \\
\hline 1107 & Fulton & Atlanta, Union City & 1970-1979 \\
\hline 1202 & DeKalb & Chamblee, Doraville \& Dunwoody & 1970-1979 \\
\hline 1203 & DeKalb & Tucker & 1970-1979 \\
\hline 1205 & DeKalb & $\mathrm{N} / \mathrm{A}$ & 1980-1989 \\
\hline 1206 & Dekalb & Redan & 1980-1989 \\
\hline 1301 & Cobb & Marietta \& Fair Oaks & 1970-1979 \\
\hline 1303 & Cobb & Smyrna \& Vinings & 1980-1989 \\
\hline 1304 & Cobb & Mableton, Smyrna, \& Austell & 1970-1979 \\
\hline 1401 & Clayton & $\begin{array}{l}\text { Forest Park } \\
\text { Outer Ring Suburbs }\end{array}$ & 1970-1979 \\
\hline 700 & Bartow \& Paulding & Cartersville & $1980-1989$ \\
\hline 800 & Dawson, Forsyth \& Pickens & N/A & 1990-1994 \\
\hline 900 & Barrow \& Walton & Winder \& Monroe & 1980-1989 \\
\hline 1101 & Fulton & Alpharetta \& Roswell & 1990-1994 \\
\hline 1302 & Cobb & $\mathrm{N} / \mathrm{A}$ & 1980-1989 \\
\hline 1305 & Cobb & Kennesaw \& Power Springs & 1990-1994 \\
\hline 1402 & Clayton & Riverdale & 1980-1989 \\
\hline 1501 & Gwinnett & Lawrenceville & 1980-1989 \\
\hline 1502 & Gwinnett & Buford, Sugar Hill \& Suwanee & 1990-1994 \\
\hline 1503 & Gwinnett & Snellville & 1980-1989 \\
\hline 1504 & Gwinnett & Lilburn \& Mountain Park & 1980-1989 \\
\hline 1505 & Gwinnett & Duluth \& Norcross & 1980-1989 \\
\hline 1600 & Newton \& Rockdale & Covington \& Conyers & 1980-1989 \\
\hline 1700 & Henry & Stockbridge & 1990-1994 \\
\hline 1800 & Carroll \& Douglas & Carrollton \& Douglasville & 1980-1989 \\
\hline 1900 & Cherokee & Woodstock & 1980-1989 \\
\hline 2000 & Coweta, Fayett, \& Spalding & $\begin{array}{l}\text { Newnan, Fayetteville, } \\
\text { Peachtree City \& Griffin }\end{array}$ & 1980-1989 \\
\hline
\end{tabular}

Source. Adapted from Liu (2012)

Note: a. City or CDP (Census Designated Place) with 10,000 or more population as of 2000. 
Appendix 2 Results for employment outcomes of latino immigrants (full sample)

\begin{tabular}{|c|c|c|c|c|c|c|}
\hline & \multicolumn{3}{|c|}{2000} & \multicolumn{3}{|c|}{2010} \\
\hline Dep. Var.: Employed & $\begin{array}{c}(1) \\
\text { Emp } \\
\text { Propensity } \\
\text { (Probit) }\end{array}$ & $\begin{array}{c}(2) \\
\text { Wage } \\
(\text { log) } \\
(\mathrm{OLS}) \\
\end{array}$ & $\begin{array}{c}(3) \\
\text { Commute } \\
\text { Time (log) } \\
\text { (OLS) }\end{array}$ & $\begin{array}{c}(4) \\
\text { Emp } \\
\text { Propensity } \\
\text { (Probit) }\end{array}$ & $\begin{array}{c}(5) \\
\text { Wage } \\
(\text { log) } \\
(\text { OLS) } \\
\end{array}$ & $\begin{array}{c}(6) \\
\text { Commute } \\
\text { Time (log) } \\
(\text { OLS) } \\
\end{array}$ \\
\hline Central city enclave & $\begin{array}{c}-0.014^{* * *} \\
(-5.17)\end{array}$ & $\begin{array}{l}-0.111^{* * *} \\
(-13.14)\end{array}$ & $\begin{array}{l}0.118^{* * *} \\
(15.24)\end{array}$ & $\begin{array}{l}0.017^{* * *} \\
(4.41)\end{array}$ & $\begin{array}{c}-0.064^{* * *} \\
(-5.91)\end{array}$ & $\begin{array}{l}0.098^{* * *} \\
(9.44)\end{array}$ \\
\hline Central city non-enclave & $\begin{array}{l}-0.010^{* * *} \\
(-3.68)\end{array}$ & $\begin{array}{c}-0.045^{* * *} \\
(-5.28)\end{array}$ & $\begin{array}{l}0.088^{* * *} \\
(11.13)\end{array}$ & $\begin{array}{l}0.030^{* * *} \\
(8.64)\end{array}$ & $\begin{array}{l}-0.013 \\
(-1.37)\end{array}$ & $\begin{array}{l}0.059^{* * *} \\
(6.49)\end{array}$ \\
\hline Inner ring suburb enclave & $\begin{array}{c}-0.014^{* * *} \\
(-5.11)\end{array}$ & $\begin{array}{l}-0.044^{* * *} \\
(-5.56)\end{array}$ & $\begin{array}{c}0.087^{* * *} \\
(11.65)\end{array}$ & $\begin{array}{l}0.024^{* * *} \\
(6.84)\end{array}$ & $\begin{array}{l}-0.019^{* *} \\
(-2.08)\end{array}$ & $\begin{array}{l}0.059^{* * *} \\
(6.65)\end{array}$ \\
\hline Inner ring suburb non-enclave & $\begin{array}{l}-0.006^{* *} \\
(-2.18)\end{array}$ & $\begin{array}{l}0.003 \\
(0.39)\end{array}$ & $\begin{array}{l}0.033^{* * *} \\
(4.53)\end{array}$ & $\begin{array}{l}0.019^{* * *} \\
(5.73)\end{array}$ & $\begin{array}{l}0.010 \\
(1.12)\end{array}$ & $\begin{array}{l}-0.001 \\
(-0.17)\end{array}$ \\
\hline Outer ring suburb enclave & $\begin{array}{l}0.002 \\
(0.64)\end{array}$ & $\begin{array}{c}-0.048^{* * *} \\
(-4.96)\end{array}$ & $\begin{array}{c}0.022^{* *} \\
(2.47)\end{array}$ & $\begin{array}{l}0.012^{* * *} \\
(3.02)\end{array}$ & $\begin{array}{l}-0.020^{*} \\
(-1.83)\end{array}$ & $\begin{array}{l}0.022^{* *} \\
(2.11)\end{array}$ \\
\hline $\begin{array}{l}\text { Household nonwage income } \\
\text { (normalized) }\end{array}$ & $\begin{array}{l}-0.002 \\
(-1.13)\end{array}$ & $\begin{array}{r}-0.010^{*} \\
(-1.74)\end{array}$ & $\begin{array}{l}0.004 \\
(0.80)\end{array}$ & $\begin{array}{c}-0.009^{* * *} \\
(-5.10)\end{array}$ & $\begin{array}{l}-0.010^{*} \\
(-1.74)\end{array}$ & $\begin{array}{l}-0.000 \\
(-0.08)\end{array}$ \\
\hline Household num of vehicles & $\begin{array}{l}0.011^{* * *} \\
(15.28)\end{array}$ & $\begin{array}{l}0.045^{* * *} \\
(21.70)\end{array}$ & $\begin{array}{l}- \\
-\end{array}$ & $\begin{array}{l}0.009^{* * *} \\
(10.03)\end{array}$ & $\begin{array}{l}0.041^{* * *} \\
(17.04)\end{array}$ & - \\
\hline Commute by public transit & $\begin{array}{l}- \\
-\end{array}$ & $\begin{array}{l}- \\
-\end{array}$ & $\begin{array}{c}0.592^{* * *} \\
(78.99)\end{array}$ & - & $\begin{array}{l}- \\
-\end{array}$ & $\begin{array}{c}0.622^{* * *} \\
(63.75)\end{array}$ \\
\hline Edu. less than highschool & $\begin{array}{c}-0.021^{* * *} \\
(-6.92)\end{array}$ & $\begin{array}{c}-0.092^{* * *} \\
(-10.06)\end{array}$ & $\begin{array}{l}-0.006 \\
(-0.73)\end{array}$ & $\begin{array}{c}-0.022^{* * *} \\
(-5.07)\end{array}$ & $\begin{array}{l}-0.010 \\
(-0.83)\end{array}$ & $\begin{array}{l}0.001 \\
(0.13)\end{array}$ \\
\hline Edu. colleg & $\begin{array}{c}0.018^{* * *} \\
(3.25)\end{array}$ & $\begin{array}{c}0.140^{* * *} \\
(9.31)\end{array}$ & $\begin{array}{l}0.015 \\
(1.07)\end{array}$ & $\begin{array}{c}0.022^{* * *} \\
(3.15)\end{array}$ & $\begin{array}{c}0.136^{* * *} \\
(7.50)\end{array}$ & $\begin{array}{l}0.015 \\
(0.84)\end{array}$ \\
\hline Age & $\begin{array}{c}0.008^{* * *} \\
(3.31)\end{array}$ & $\begin{array}{c}0.070^{* * *} \\
(10.29)\end{array}$ & $\begin{array}{l}0.012^{*} \\
(1.96)\end{array}$ & $\begin{array}{c}0.011^{* * *} \\
(3.44)\end{array}$ & $\begin{array}{c}0.121^{* * *} \\
(14.74)\end{array}$ & $\begin{array}{l}0.012 \\
(1.53)\end{array}$ \\
\hline Age squared & $\begin{array}{c}0.000^{* *} \\
(-2.13)\end{array}$ & $\begin{array}{l}-0.000 \\
(-0.87)\end{array}$ & $\begin{array}{l}-0.000 \\
(-0.20)\end{array}$ & $\begin{array}{c}-0.000^{* * *} \\
(-4.28)\end{array}$ & $\begin{array}{c}-0.000^{* * *} \\
(-5.70)\end{array}$ & $\begin{array}{l}0.000 \\
(0.24)\end{array}$ \\
\hline Experience & $\begin{array}{l}-0.001 \\
(-0.63)\end{array}$ & $\begin{array}{c}-0.019^{* * *} \\
(-4.01)\end{array}$ & $\begin{array}{l}-0.006 \\
(-1.31)\end{array}$ & $\begin{array}{l}-0.000 \\
(-0.03)\end{array}$ & $\begin{array}{c}-0.050^{* * *} \\
(-8.29)\end{array}$ & $\begin{array}{l}-0.006 \\
(-1.00)\end{array}$ \\
\hline Experience squared & $\begin{array}{l}-0.000 \\
(-0.96)\end{array}$ & $\begin{array}{c}-0.001^{* \star *} \\
(-11.72)\end{array}$ & $\begin{array}{l}-0.000 \\
(-1.35)\end{array}$ & $\begin{array}{l}0.000 \\
(0.57)\end{array}$ & $\begin{array}{c}-0.001^{* \star *} \\
(-6.82)\end{array}$ & $\begin{array}{c}-0.000^{*} \\
(-1.74)\end{array}$ \\
\hline Female & $\begin{array}{c}-0.050^{\star * *} \\
(-29.12)\end{array}$ & $\begin{array}{c}-0.387^{* * *} \\
(-69.19)\end{array}$ & $\begin{array}{c}-0.093^{* * *} \\
(-17.93)\end{array}$ & $\begin{array}{c}-0.038^{* * *} \\
(-17.04)\end{array}$ & $\begin{array}{c}-0.381^{* * *} \\
(-58.10)\end{array}$ & $\begin{array}{c}-0.107^{\star \star *} \\
(-16.82)\end{array}$ \\
\hline Children & $\begin{array}{l}-0.001 \\
(-0.53)\end{array}$ & $\begin{array}{c}0.089^{* * *} \\
(13.40)\end{array}$ & $\begin{array}{c}0.020^{* * *} \\
(3.21)\end{array}$ & $\begin{array}{l}0.000 \\
(0.13)\end{array}$ & $\begin{array}{c}0.073^{* * *} \\
(8.71)\end{array}$ & $\begin{array}{c}0.027^{* * *} \\
(3.34)\end{array}$ \\
\hline Married & $\begin{array}{c}0.007^{* * *} \\
(3.55)\end{array}$ & $\begin{array}{c}0.062^{* * *} \\
(10.64)\end{array}$ & $\begin{array}{l}-0.003 \\
(-0.58)\end{array}$ & $\begin{array}{l}0.000 \\
(0.05)\end{array}$ & $\begin{array}{c}0.048^{* * *} \\
(7.01)\end{array}$ & $\begin{array}{l}0.001 \\
(0.15)\end{array}$ \\
\hline $\begin{array}{l}\text { Immigration in last } 10 \text { years } \\
(1990-2000)\end{array}$ & $\begin{array}{c}0.000 \\
(-0.10)\end{array}$ & $\begin{array}{l}-0.116^{* * *} \\
(-17.31)\end{array}$ & $\begin{array}{c}-0.039^{* * *} \\
(-6.39)\end{array}$ & $\begin{array}{l}0.003 \\
(1.13)\end{array}$ & $\begin{array}{l}-0.147^{* * *} \\
(-19.01)\end{array}$ & $\begin{array}{c}-0.047^{* * *} \\
(-6.46)\end{array}$ \\
\hline $\begin{array}{l}\text { Immigration in } 20-30 \text { years } \\
(1970-79)\end{array}$ & $\begin{array}{l}0.003 \\
(1.13)\end{array}$ & $\begin{array}{c}0.146^{* * *} \\
(20.47)\end{array}$ & $\begin{array}{c}0.017^{* *} \\
(2.55)\end{array}$ & $\begin{array}{l}0.003 \\
(0.84)\end{array}$ & $\begin{array}{c}0.108^{* * *} \\
(11.23)\end{array}$ & $\begin{array}{l}-0.015 \\
(-1.59)\end{array}$ \\
\hline $\begin{array}{l}\text { Immigration over } 30 \text { years } \\
\text { (before 1970) }\end{array}$ & $\begin{array}{l}0.010^{* *} \\
(2.34)\end{array}$ & $\begin{array}{c}0.295^{* * *} \\
(26.39)\end{array}$ & $\begin{array}{l}0.002 \\
(0.20)\end{array}$ & $\begin{array}{c}0.018^{* * *} \\
(2.94)\end{array}$ & $\begin{array}{l}0.244^{* * *} \\
(15.27)\end{array}$ & $\begin{array}{l}-0.031^{* *} \\
(-2.00)\end{array}$ \\
\hline Speak English only & $\begin{array}{l}-0.018^{* * *} \\
(-4.65)\end{array}$ & $\begin{array}{l}0.086^{* * *} \\
(6.76)\end{array}$ & $\begin{array}{l}0.036^{* * *} \\
(3.10)\end{array}$ & $\begin{array}{l}0.006 \\
(0.97)\end{array}$ & $\begin{array}{l}0.263^{* * *} \\
(15.74)\end{array}$ & $\begin{array}{l}0.062^{* \star *} \\
(3.86)\end{array}$ \\
\hline Speak English well & $\begin{array}{c}0.017^{\star * *} \\
(8.76)\end{array}$ & $\begin{array}{l}0.161^{* * *} \\
(26.96)\end{array}$ & $\begin{array}{l}0.023^{\star * *} \\
(4.11)\end{array}$ & $\begin{array}{c}0.015^{\star * *} \\
(5.85)\end{array}$ & $\begin{array}{l}0.201^{* * *} \\
(28.80)\end{array}$ & $\begin{array}{c}0.044^{* * *} \\
(6.63)\end{array}$ \\
\hline Manufacturing & - & $\begin{array}{l}0.072^{* * *} \\
(8.39)\end{array}$ & $\begin{array}{l}-0.202^{* * *} \\
(-25.80)\end{array}$ & $\begin{array}{l}- \\
-\end{array}$ & $\begin{array}{l}0.089^{* * *} \\
(8.54)\end{array}$ & $\begin{array}{c}-0.205^{\star * *} \\
(-20.71)\end{array}$ \\
\hline Trade & - & $-0.068^{* * *}$ & $-0.316^{* * *}$ & - & $-0.074^{* * *}$ & $-0.334^{* * *}$ \\
\hline
\end{tabular}


Appendix 3 Results for employment outcomes of latino immigrants who are relatives of householders (new arrivals versus established immigrants)

\begin{tabular}{|c|c|c|c|c|c|c|c|}
\hline \multirow{2}{*}{\multicolumn{2}{|c|}{ thes }} & \multicolumn{3}{|c|}{2000} & \multicolumn{3}{|c|}{2010} \\
\hline & & $\begin{array}{c}\text { Employment } \\
\text { Propensity }\end{array}$ & $\begin{array}{l}\text { Wage } \\
(\log )\end{array}$ & $\begin{array}{l}\text { Commute } \\
\text { Time (log) }\end{array}$ & $\begin{array}{l}\text { Employment } \\
\text { Propensity }\end{array}$ & $\begin{array}{r}\text { Wage } \\
(\log )\end{array}$ & $\begin{array}{l}\text { Commute } \\
\text { Time (log) }\end{array}$ \\
\hline \multirow{7}{*}{$\begin{array}{l}\text { New Arrivals } \\
\text { (arrived less } \\
\text { than } 10 \text { years }\end{array}$} & Central city enclave & $\begin{array}{c}-0.023^{* * *} \\
(-3.26)\end{array}$ & $\begin{array}{c}-0.062^{* * *} \\
(-2.89)\end{array}$ & $\begin{array}{c}0.162^{* * *} \\
(9.15)\end{array}$ & $\begin{array}{c}0.026^{* \star *} \\
(2.72)\end{array}$ & $\begin{array}{l}0.011 \\
(0.45)\end{array}$ & $\begin{array}{c}0.147^{* \star *} \\
(6.84)\end{array}$ \\
\hline & Central city non-enclave & $\begin{array}{l}-0.013^{*} \\
(-1.74)\end{array}$ & $\begin{array}{l}-0.033 \\
(-1.40)\end{array}$ & $\begin{array}{c}0.144^{* * *} \\
(7.55)\end{array}$ & $\begin{array}{c}0.028^{* * *} \\
(3.18)\end{array}$ & $\begin{array}{l}0.024 \\
(1.03)\end{array}$ & $\begin{array}{c}0.133^{* * *} \\
(6.58)\end{array}$ \\
\hline & Inner ring suburb enclave & $\begin{array}{l}-0.012^{*} \\
(-1.65)\end{array}$ & $\begin{array}{l}0.035^{*} \\
(1.66)\end{array}$ & $\begin{array}{c}0.150^{* * *} \\
(8.66)\end{array}$ & $\begin{array}{c}0.018^{* *} \\
(2.13)\end{array}$ & $\begin{array}{c}0.093^{* * *} \\
(4.18)\end{array}$ & $\begin{array}{c}0.128^{* * *} \\
(6.62)\end{array}$ \\
\hline & Inner ring suburb non-enclave & $\begin{array}{c}-0.015^{\star *} \\
(-2.04)\end{array}$ & $\begin{array}{l}0.007 \\
(0.34)\end{array}$ & $\begin{array}{l}0.020 \\
(1.13)\end{array}$ & $\begin{array}{c}0.017^{* *} \\
(2.02)\end{array}$ & $\begin{array}{l}0.013 \\
(0.58)\end{array}$ & $\begin{array}{l}0.026 \\
(1.37)\end{array}$ \\
\hline & Outer ring suburb enclave & $\begin{array}{l}0.005 \\
(0.65)\end{array}$ & $\begin{array}{l}0.010 \\
(0.43)\end{array}$ & $\begin{array}{c}0.069^{* * *} \\
(3.58)\end{array}$ & $\begin{array}{l}0.02^{\star *} \\
(2.03)\end{array}$ & $\begin{array}{l}0.049^{*} \\
(1.91)\end{array}$ & $\begin{array}{c}0.099^{* * *} \\
(4.46)\end{array}$ \\
\hline & Observations & 19663 & 14575 & 15,685 & 14678 & 12037 & 12,430 \\
\hline & R2 or Pseudo R2 & 0.04 & 0.10 & 0.14 & 0.03 & 0.15 & 0.14 \\
\hline \multirow{7}{*}{$\begin{array}{l}\text { Established } \\
\text { Immigrants } \\
\text { (arrived more } \\
\text { than } 10 \text { years }\end{array}$} & Central city enclave & $\begin{array}{l}-0.011 \\
(-1.42)\end{array}$ & $\begin{array}{c}-0.069^{* * *} \\
(-3.13)\end{array}$ & $\begin{array}{c}0.087^{* * *} \\
(4.53)\end{array}$ & $\begin{array}{l}0.022 \\
(1.55)\end{array}$ & $\begin{array}{l}-0.036 \\
(-1.00)\end{array}$ & $\begin{array}{l}0.071^{* *} \\
(2.13)\end{array}$ \\
\hline & Central city non-enclave & $\begin{array}{l}0.004 \\
(0.48)\end{array}$ & $\begin{array}{l}-0.009 \\
(-0.41)\end{array}$ & $\begin{array}{c}0.092^{\star \star \star} \\
(4.64)\end{array}$ & $\begin{array}{c}0.037^{\star * *} \\
(2.91)\end{array}$ & $\begin{array}{l}-0.021 \\
(-0.64)\end{array}$ & $\begin{array}{l}0.053^{*} \\
(1.78)\end{array}$ \\
\hline & Inner ring suburb enclave & $\begin{array}{c}-0.014^{* *} \\
(-1.97)\end{array}$ & $\begin{array}{l}0.005 \\
(0.23)\end{array}$ & $\begin{array}{c}0.079^{* * *} \\
(4.31)\end{array}$ & $\begin{array}{l}0.022^{*} \\
(1.80)\end{array}$ & $\begin{array}{l}-0.019 \\
(-0.61)\end{array}$ & $\begin{array}{l}0.028 \\
(0.97)\end{array}$ \\
\hline & Inner ring suburb non-enclave & $\begin{array}{l}-0.004 \\
(-0.48)\end{array}$ & $\begin{array}{l}0.001 \\
(0.06)\end{array}$ & $\begin{array}{c}0.045^{\star *} \\
(2.44)\end{array}$ & $\begin{array}{c}0.01 \\
(0.85)\end{array}$ & $\begin{array}{c}0.083^{* * *} \\
(2.61)\end{array}$ & $\begin{array}{l}-0.023 \\
(-0.80)\end{array}$ \\
\hline & Outer ring suburb enclave & $\begin{array}{l}0.006 \\
(0.63)\end{array}$ & $\begin{array}{l}0.046^{*} \\
(1.81)\end{array}$ & $\begin{array}{l}0.006 \\
(0.25)\end{array}$ & $\begin{array}{l}0.007 \\
(0.45)\end{array}$ & $\begin{array}{l}-0.053 \\
(-1.31)\end{array}$ & $\begin{array}{l}-0.013 \\
(-0.34)\end{array}$ \\
\hline & Observations & 16992 & 13490 & 14,237 & 6753 & 5468 & 5,615 \\
\hline & $R 2$ or Pseudo R2 & 0.04 & 0.17 & 0.10 & 0.01 & 0.15 & 0.10 \\
\hline
\end{tabular}


Appendix 4 Results for employment outcomes of African Americans

\begin{tabular}{|c|c|c|c|c|c|c|}
\hline & \multicolumn{3}{|c|}{2000} & \multicolumn{3}{|c|}{2010} \\
\hline $\begin{array}{l}\text { Dep. Var.: Employed } \\
\text { Independent Variables }\end{array}$ & $\begin{array}{c}(1) \\
\text { Emp } \\
\text { Propensity } \\
\text { (Probit) } \\
\end{array}$ & $\begin{array}{c}(2) \\
\text { Wage } \\
\text { (log) } \\
\text { (OLS) } \\
\end{array}$ & $\begin{array}{c}\text { (3) } \\
\text { Commute } \\
\text { Time (log) } \\
\text { (OLS) } \\
\end{array}$ & $\begin{array}{c}\text { (4) } \\
\text { Emp } \\
\text { Propensity } \\
\text { (Probit) }\end{array}$ & $\begin{array}{c}\text { (5) } \\
\text { Wage } \\
\text { (log) } \\
\text { (OLS) } \\
\end{array}$ & $\begin{array}{c}\text { (6) } \\
\text { Commute } \\
\text { Time (log) } \\
\text { (OLS) } \\
\end{array}$ \\
\hline Central city enclave & $\begin{array}{c}-0.223^{* *} \\
(-2.23)\end{array}$ & $\begin{array}{c}-0.140^{* * *} \\
(-3.07)\end{array}$ & $\begin{array}{l}-0.097^{* *} \\
(-2.52)\end{array}$ & $\begin{array}{l}-0.068 \\
(-0.63)\end{array}$ & $\begin{array}{l}-0.086 \\
(-1.51)\end{array}$ & $\begin{array}{l}-0.104^{* *} \\
(-2.20)\end{array}$ \\
\hline Central city non-enclave & $\begin{array}{l}-0.157^{*} \\
(-1.94)\end{array}$ & $\begin{array}{c}-0.099^{* * *} \\
(-2.85)\end{array}$ & $\begin{array}{c}-0.117^{* \star *} \\
(-4.02)\end{array}$ & $\begin{array}{l}0.028 \\
(0.38)\end{array}$ & $\begin{array}{l}-0.008 \\
(-0.22)\end{array}$ & $\begin{array}{c}-0.206^{* * *} \\
(-6.67)\end{array}$ \\
\hline Inner ring suburb enclave & $\begin{array}{l}0.004 \\
(0.05)\end{array}$ & $\begin{array}{c}-0.105^{\star * *} \\
(-3.42)\end{array}$ & $\begin{array}{c}-0.069^{* * *} \\
(-2.66)\end{array}$ & $\begin{array}{l}-0.023 \\
(-0.34)\end{array}$ & $\begin{array}{l}-0.057^{*} \\
(-1.68)\end{array}$ & $\begin{array}{l}-0.068^{* *} \\
(-2.40)\end{array}$ \\
\hline Inner ring suburb non-enclave & $\begin{array}{l}0.029 \\
(0.39)\end{array}$ & $\begin{array}{l}-0.033 \\
(-1.16)\end{array}$ & $\begin{array}{l}0.012 \\
(0.51)\end{array}$ & $\begin{array}{l}-0.097^{*} \\
(-1.85)\end{array}$ & $\begin{array}{l}0.039 \\
(1.46)\end{array}$ & $\begin{array}{l}-0.024 \\
(-1.06)\end{array}$ \\
\hline Outer ring suburb enclave & $\begin{array}{l}0.099 \\
(0.73)\end{array}$ & $\begin{array}{l}-0.075 \\
(-1.47)\end{array}$ & $\begin{array}{l}-0.071 \\
(-1.64)\end{array}$ & $\begin{array}{l}0.016 \\
(0.20)\end{array}$ & $\begin{array}{l}0.051 \\
(1.33)\end{array}$ & $\begin{array}{l}-0.038 \\
(-1.19)\end{array}$ \\
\hline $\begin{array}{l}\text { Household nonwage income } \\
\text { (normalized) }\end{array}$ & $\begin{array}{l}-0.051 \\
(-1.36)\end{array}$ & $\begin{array}{l}-0.038^{*} \\
(-1.78)\end{array}$ & $\begin{array}{l}-0.032^{\star *} \\
(-2.34)\end{array}$ & $\begin{array}{c}-0.079^{* *} \\
(-2.36)\end{array}$ & $\begin{array}{l}-0.012 \\
(-0.56)\end{array}$ & $\begin{array}{l}-0.034^{\star *} \\
(-2.18)\end{array}$ \\
\hline Household num of vehicles & $\begin{array}{l}0.147^{\star \star *} \\
(5.77)\end{array}$ & $\begin{array}{l}0.056^{* \star *} \\
(5.58)\end{array}$ & - & $\begin{array}{l}0.058^{\star \star *} \\
(2.93)\end{array}$ & $\begin{array}{c}0.058^{* * *} \\
(5.75)\end{array}$ & $\begin{array}{l}- \\
-\end{array}$ \\
\hline Commute by public transit & $\begin{array}{l}- \\
-\end{array}$ & $\begin{array}{l}- \\
-\end{array}$ & $\begin{array}{l}0.505^{* * *} \\
(21.57)\end{array}$ & - & - & $\begin{array}{c}0.590^{* * *} \\
(23.81)\end{array}$ \\
\hline Edu. less than highschool & $\begin{array}{c}-0.185^{\star *} \\
(-2.40)\end{array}$ & $\begin{array}{c}-0.137^{\star * *} \\
(-3.65)\end{array}$ & $\begin{array}{l}-0.027 \\
(-0.84)\end{array}$ & $\begin{array}{l}-0.036 \\
(-0.46)\end{array}$ & $\begin{array}{l}0.013 \\
(0.28)\end{array}$ & $\begin{array}{l}-0.010 \\
(-0.27)\end{array}$ \\
\hline Edu. college degree or above & $\begin{array}{l}0.080 \\
(0.72)\end{array}$ & $\begin{array}{l}0.011 \\
(0.24)\end{array}$ & $\begin{array}{l}0.064^{*} \\
(1.66)\end{array}$ & $\begin{array}{l}0.055 \\
(0.58)\end{array}$ & $\begin{array}{l}0.072 \\
(1.52)\end{array}$ & $\begin{array}{l}0.002 \\
(0.04)\end{array}$ \\
\hline Age & $\begin{array}{c}0.262^{* * *} \\
(5.07)\end{array}$ & $\begin{array}{c}0.270^{* * *} \\
(11.46)\end{array}$ & $\begin{array}{l}0.011 \\
(0.54)\end{array}$ & $\begin{array}{c}0.221^{* * *} \\
(4.79)\end{array}$ & $\begin{array}{c}0.277^{* * *} \\
(11.10)\end{array}$ & $\begin{array}{c}0.066^{* * *} \\
(3.18)\end{array}$ \\
\hline Age squared & $\begin{array}{c}-0.003^{* * *} \\
(-5.11)\end{array}$ & $\begin{array}{c}-0.002^{* * *} \\
(-7.53)\end{array}$ & $\begin{array}{l}-0.000 \\
(-0.72)\end{array}$ & $\begin{array}{c}-0.002^{* * *} \\
(-4.50)\end{array}$ & $\begin{array}{c}-0.002^{* * *} \\
(-7.13)\end{array}$ & $\begin{array}{c}-0.000^{* *} \\
(-2.35)\end{array}$ \\
\hline Experience & $\begin{array}{c}-0.108^{* * *} \\
(-2.81)\end{array}$ & $\begin{array}{c}-0.139^{* \star *} \\
(-8.43)\end{array}$ & $\begin{array}{l}0.005 \\
(0.37)\end{array}$ & $\begin{array}{c}-0.087^{* *} \\
(-2.54)\end{array}$ & $\begin{array}{c}-0.135^{\star \star *} \\
(-7.59)\end{array}$ & $\begin{array}{c}-0.040^{\star * *} \\
(-2.72)\end{array}$ \\
\hline Experience squared & $\begin{array}{c}0.002^{* * *} \\
(3.20)\end{array}$ & $\begin{array}{c}0.001^{* * *} \\
(3.13)\end{array}$ & $\begin{array}{l}-0.000 \\
(-0.18)\end{array}$ & $\begin{array}{c}0.001^{* *} \\
(2.15)\end{array}$ & $\begin{array}{l}0.000 \\
(1.51)\end{array}$ & $\begin{array}{l}0.000^{*} \\
(1.87)\end{array}$ \\
\hline Female & $\begin{array}{l}0.043 \\
(0.92)\end{array}$ & $\begin{array}{c}-0.160^{* * *} \\
(-8.07)\end{array}$ & $\begin{array}{c}-0.041^{* *} \\
(-2.41)\end{array}$ & $\begin{array}{l}0.014 \\
(0.36)\end{array}$ & $\begin{array}{c}-0.179^{\star * *} \\
(-8.52)\end{array}$ & $\begin{array}{l}-0.012 \\
(-0.68)\end{array}$ \\
\hline Children & $\begin{array}{c}-0.246^{* * *} \\
(-3.85)\end{array}$ & $\begin{array}{l}0.045^{\star} \\
(1.70)\end{array}$ & $\begin{array}{c}0.045^{* *} \\
(2.03)\end{array}$ & $\begin{array}{l}-0.035 \\
(-0.61)\end{array}$ & $\begin{array}{l}0.009 \\
(0.30)\end{array}$ & $\begin{array}{l}0.037 \\
(1.56)\end{array}$ \\
\hline Married & $\begin{array}{c}0.159^{* * *} \\
(2.92)\end{array}$ & $\begin{array}{l}0.007 \\
(0.32)\end{array}$ & $\begin{array}{l}0.009 \\
(0.52)\end{array}$ & $\begin{array}{l}0.025 \\
(0.53)\end{array}$ & $\begin{array}{l}0.043^{*} \\
(1.88)\end{array}$ & $\begin{array}{l}0.011 \\
(0.58)\end{array}$ \\
\hline $\begin{array}{c}\text { Immigration in last } 10 \text { years } \\
(1990-2000)\end{array}$ & $\begin{array}{l}0.029 \\
(0.52)\end{array}$ & $\begin{array}{c}-0.175^{* * *} \\
(-7.53)\end{array}$ & $\begin{array}{c}-0.063^{* * *} \\
(-3.18)\end{array}$ & $\begin{array}{l}-0.064 \\
(-1.20)\end{array}$ & $\begin{array}{l}-0.189^{* * *} \\
(-7.38)\end{array}$ & $\begin{array}{c}-0.066^{* * *} \\
(-3.11)\end{array}$ \\
\hline $\begin{array}{l}\text { Immigration in } 20-30 \text { years } \\
(1970-79)\end{array}$ & $\begin{array}{l}0.054 \\
(0.74)\end{array}$ & $\begin{array}{c}0.093^{* * *} \\
(3.35)\end{array}$ & $\begin{array}{l}0.024 \\
(1.04)\end{array}$ & $\begin{array}{l}-0.092 \\
(-1.25)\end{array}$ & $\begin{array}{l}0.033 \\
(0.93)\end{array}$ & $\begin{array}{l}-0.007 \\
(-0.24)\end{array}$ \\
\hline $\begin{array}{l}\text { Immigration over } 30 \text { years } \\
\text { (before 1970) }\end{array}$ & $\begin{array}{l}0.132 \\
(1.18)\end{array}$ & $\begin{array}{l}0.231^{* * *} \\
(5.30)\end{array}$ & $\begin{array}{l}0.058 \\
(1.57)\end{array}$ & $\begin{array}{l}0.018 \\
(0.15)\end{array}$ & $\begin{array}{l}0.231^{* * *} \\
(3.94)\end{array}$ & $\begin{array}{l}0.041 \\
(0.83)\end{array}$ \\
\hline Speak English only & $\begin{array}{l}0.197^{*} \\
(1.74)\end{array}$ & $\begin{array}{l}0.130^{* *} \\
(2.20)\end{array}$ & $\begin{array}{l}0.003 \\
(0.07)\end{array}$ & $\begin{array}{l}0.290^{* * *} \\
(3.32)\end{array}$ & $\begin{array}{c}0.238^{* \star *} \\
(4.43)\end{array}$ & $\begin{array}{l}0.083^{*} \\
(1.88)\end{array}$ \\
\hline Speak English well & $\begin{array}{l}0.155 \\
(1.39)\end{array}$ & $\begin{array}{l}0.028 \\
(0.47)\end{array}$ & $\begin{array}{l}-0.030 \\
(-0.61)\end{array}$ & $\begin{array}{c}0.328^{* * *} \\
(3.87)\end{array}$ & $\begin{array}{l}0.113^{* *} \\
(2.16)\end{array}$ & $\begin{array}{l}0.045 \\
(1.04)\end{array}$ \\
\hline Manufacturing & - & $\begin{array}{l}0.046 \\
(0.66)\end{array}$ & $\begin{array}{l}-0.063 \\
(-1.10)\end{array}$ & $\begin{array}{l}- \\
-\end{array}$ & $\begin{array}{l}0.045 \\
(0.66)\end{array}$ & $\begin{array}{l}-0.102^{*} \\
(-1.82)\end{array}$ \\
\hline Trade & - & $-0.270^{* * *}$ & $-0.218^{* \star *}$ & - & $-0.380^{* * *}$ & $-0.306^{\star * *}$ \\
\hline
\end{tabular}


